\title{
ADSORPTION AND DESORPTION OF 2,4,6-TRINITROTOLUENE BY SOILS
}

\author{
by \\ Judith C. Pennington \\ Environmental Laboratory \\ DEPARTMENT OF THE ARMY \\ Waterways Experiment Station, Corps of Engineers \\ PO Box 631, Vicksburg, Mississippi 39180-0631
}
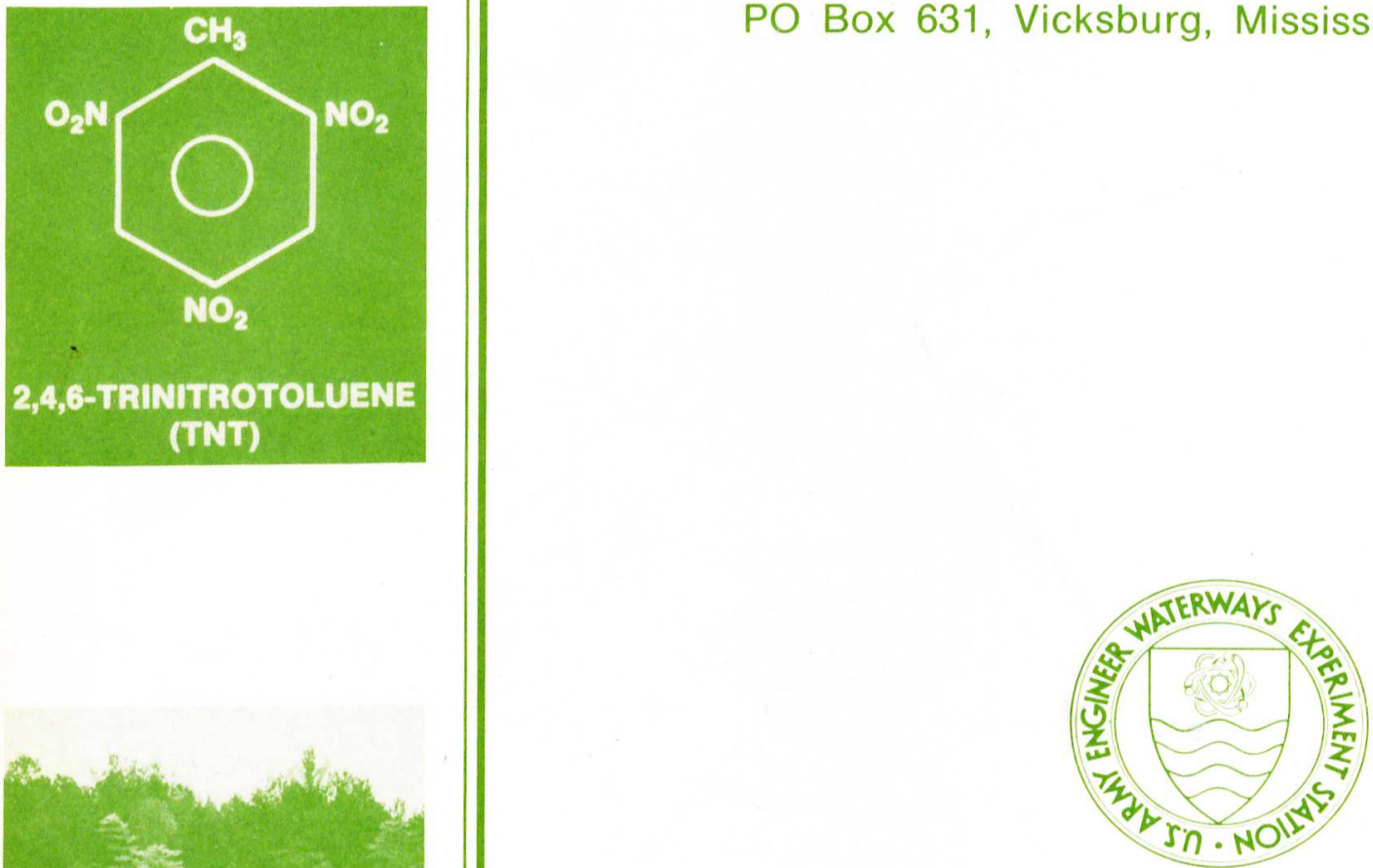

November 1987

Final Report

Approved For Public Release, Distribution Unlimited

\author{
Library Branch \\ Technical Information Center \\ U.S. Army Engineer Waterways Experiment Station \\ Vicksburg, Mississippi
}

\author{
Prepared for DEPARTMENT OF THE ARMY \\ Assistant Secretary of the Army (R\&D) \\ Washington, DC 20315 \\ Under Project No. 4A161101A91D
}


Destroy this report when no longer needed. Do not return it to the originator.

The findings in this report are not to be construed as an official Department of the Army position unless so designated by other authorized documents.

The contents of this report are not to be used for advertising, publication, or promotional purposes. Citation of trade names does not constitute an official endorsement or approval of the use of such commercial products.

Preparation of this report was sponsored by the Department of the Army In-House Laboratory Independent Research Program. Neither the Department of the Army, nor the US Army Corps of Engineers, nor their employees, nor any of their contractors, subcontractors, or their employees makes any warranty, expressed or implied, or assumes any legal liability or responsibility for the accuracy, completeness, or usefullness of any information, apparatus, product, or process disclosed, or represents that its use would not infringe privately owned rights.

TA7 W34 nO.EL-87-17 C.2

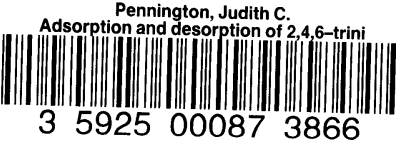




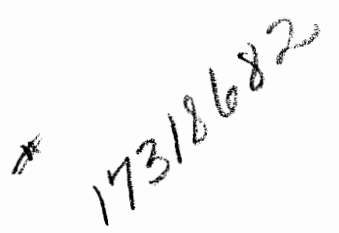

Unclassified

SECURITY CLASSIFICATION OF THIS PAGE

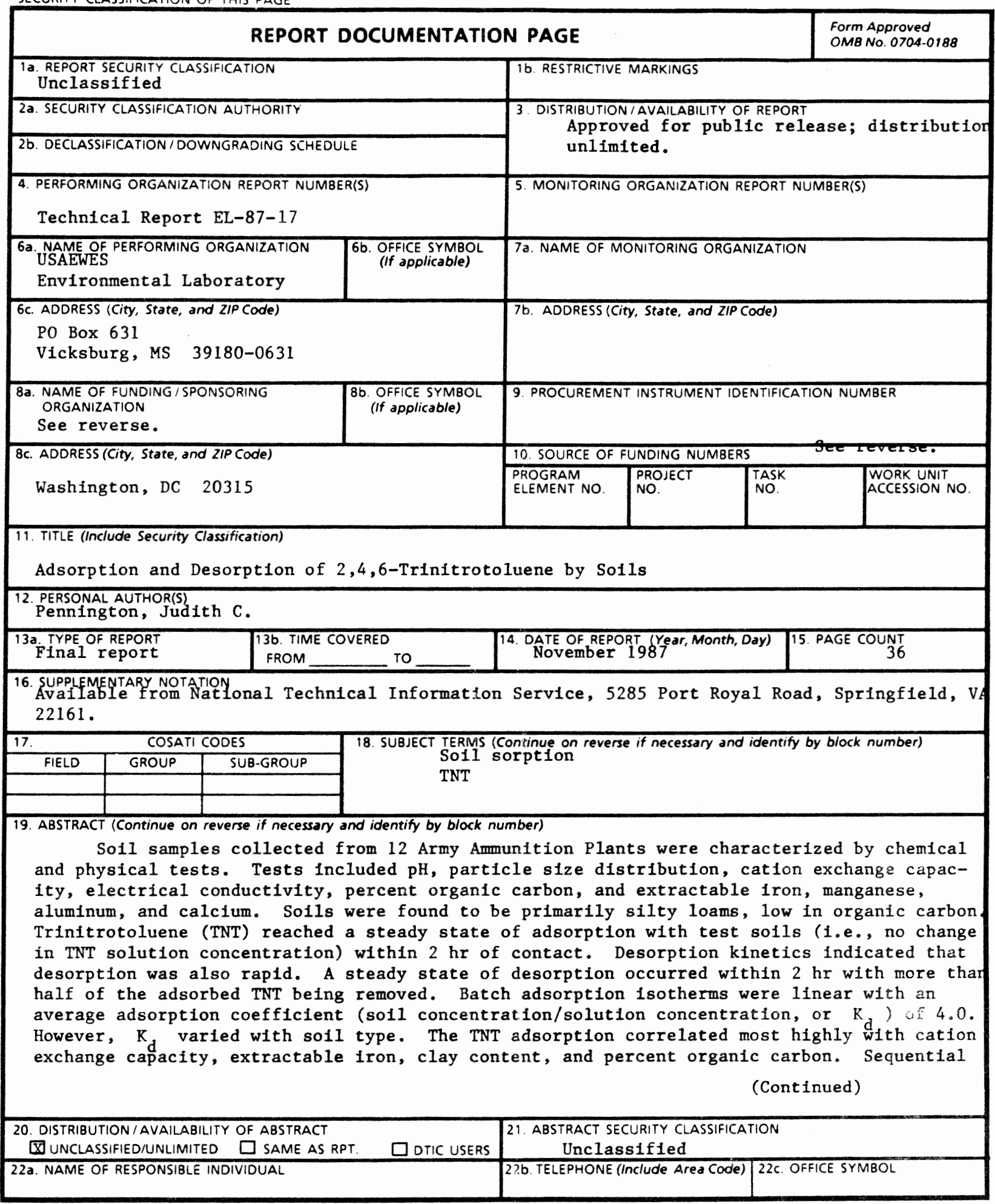


Unclassified

SECURTY CLASSIFTCATON OF THIS PACE

8a. FUNDING/SPONSORING ORGANIZATION (Continued).

DEPARTMENT OF THE ARMY

Assistant Secretary of the Army (R\&D)

10. SOURCE OF FUNDING NUMBERS (Continued).

ILIR Project No. 4A161101A91D

19. ABSTRACT (Continued).

desorption indicated that almost all of the adsorbed TNT was desorbed after three desorption cycles. Therefore, soil sorption of TNT will not effectively prevent mobility of TNT in the environment unless more strongly adsorbed degradation products are formed. 
This report describes a study of 2,4,6-trinitrotoluene adsorption and desorption by soils from selected US Army Ammunition Plants. The study was conducted by the Environmental Laboratory (EL) of the US Army Engineer Waterways Experiment Station (WES), Vicksburg, Miss. The research was sponsored by the Department of the Army In-House Laboratory Independent Research (ILIR) Program for FY 86 and 87, under ILIR Project No. 4A161101A91D.

The study was conducted by Mrs. Judith C. Pennington of the Plant Bioassay Team at WES. Technical assistance was provided by Team members Mr. Mark Cooper and Mrs. Joycie Bright. Assistance with statistics was received from Mr. Dennis L. Brandon. The report was edited by Ms. Jessica S. Ruff of the WES Information Technology Laboratory.

Team Leader for the Plant Bioassay Team during the study was Dr. Bobby L. Folsom, Jr. The study was conducted under the general supervision of Dr. Charles R. Lee, Chief, Contaminant Mobility and Regulatory Criteria Group; Mr. Donald L. Robey, Chief, Ecosystem Research and Simulation Division; and Dr. John Harrison, Chief, EL.

COL Dwayne G. Lee, CE, was the Commander and Director of WES. Dr. Robert W. Whalin was Technical Director.

This report should be cited as follows:

Pennington, Judith C. 1987. "Adsorption and Desorption of 2,4,6-Trinitrotoluene by Soils," Technical Report EL-87-17, US Army Engineer Waterways Experiment Station, Vicksburg, Miss. 
PREFACE...............................................

PART I: INTRODUCTION ................................

Background ........................................ 3

objectives....................................... 4

PART II: MATERIALS AND METHODS............................ 5

Soil Collection......................................

Physical and Chemical Characterization of Soils.............. 6

Soil to Solution Ratio................................ 7

Adsorption Kinetics................................. 8

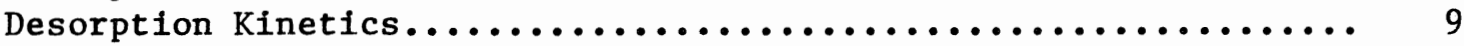

Batch Adsorption Equilibrium........................... 10

Sequential Desorption................................ 10

PART III: $\operatorname{RESULTS}$ AND DISCUSSION .......................... 11

Soil Characterization............................... 11

Soil to Solution Ratio................................11

Adsorption Kinetics.................................. 11

Desorption Kinetics................................... 14

Batch Adsorption Equilibrium and Sequential Desorption......... 16

Environmental Consequences of Adsorption/Desorption

Properties of TNT................................. 21

PART IV: CONCLUSIONS................................... 22

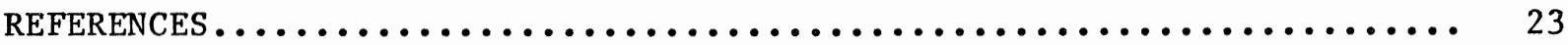

APPENDIX A: STANDARD CURVES ............................. A1 
ADSORPTION AND DESORPTION OF 2,4,6-TRINITROTOLUENE BY SOILS

\section{PART I: INTRODUCTION}

\section{Background}

1. Disposal of effluents from the manufacture of the explosive 2,4,6-trinitrotoluene (TNT) and wastewater from cleaning TNT-containing bomb and shell castings has resulted in confirmed cases of contamination of ground water or soil on almost half of the 30 Army Ammunition Plants (AAPs) where TNT has been manufactured or loaded (Tucker et al. 1985). TNT and many of its degradation products are known to be toxic to fish and other aquatic fauna (Osmon and Klausmeier 1972; Nay, Randa11, and King 1974; Liu, Spanggord, and

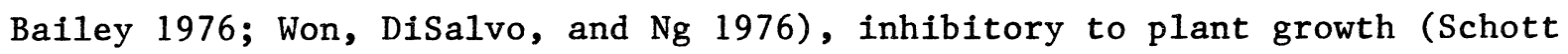
and Worthley 1974, Lakings and Gan 1981, Palazzo and Leggett 1986), and, in some cases, mutagenic (Won, DiSalvo, and Ng 1976; Dilley, Tyson, and Newell 1978; Kaplan and Kaplan 1982a, 1982b).

2. TNT and/or its degradation products may be irreversibly adsorbed to soils and sediments. Irreversible adsorption was suggested as the mechanism for loss of TNT from TNT-treated bentonite drilling muds (Leggett 1985), from TNT-treated soils upon subsequent drying (Cragin et al., 1985), and from TNTtreated river sediment (Spanggord et al. 1980, 1983). Studies of plant adsorption of TNT showed significantly greater uptake from hydroponic solutions (Palazzo et al. 1985) than from soils (Folsom et al., in preparation). These results suggest that the compound may become adsorbed to soils or to soil organic matter.

3. In a previous study by Pennington (in preparation), comparison of ${ }^{14} \mathrm{C}$ recovered from $\left[{ }^{14} \mathrm{C}\right] \mathrm{TNT}$-treated soils by solvent extraction and by a complete combustion technique showed that approximately 20 percent of the added TNT was unextractable. Lack of extractability suggests irreversible adsorption, or extremely slow desorption, of TNT or its degradation products.

4. Determination of the extent of adsorption and identification of soil properties associated with adsorption of TNT in soils will assist in definition of the problem in contaminated areas and provide a basis for predicting the extent and duration of environmental impacts. Study of soil/TNT 
interactions will also contribute to the basic understanding necessary for development of cleanup procedures on TNT-contaminated sites.

\section{Objectives}

5. Objectives of this study were to:

a. Quantify the rate and extent of adsorption and desorption of TNT to soils from 12 AAPs.

b. Determine what soil characteristics correlate most closely with adsorption of TNT. 


\section{$\underline{\text { Soil Collection }}$}

6. Locations of AAPs that were sampled for this study are shown in Figure 1. Soil samples were collected from uncontaminated sites at 12 of the AAPs that handle TNT now or have handled TNT in the past. Seven of the 14 installations having documented TNT contamination of ground water or soil in the data base of the US Army Toxic and Hazardous Materials Agency (USATHAMA) (Tucker et al. 1985) were sampled. Five of the AAPs sampled are listed by USATHAMA as potentially contaminated with TNT. The remaining AAP sampled was reported by installation personnel as having handled TNT in the past.

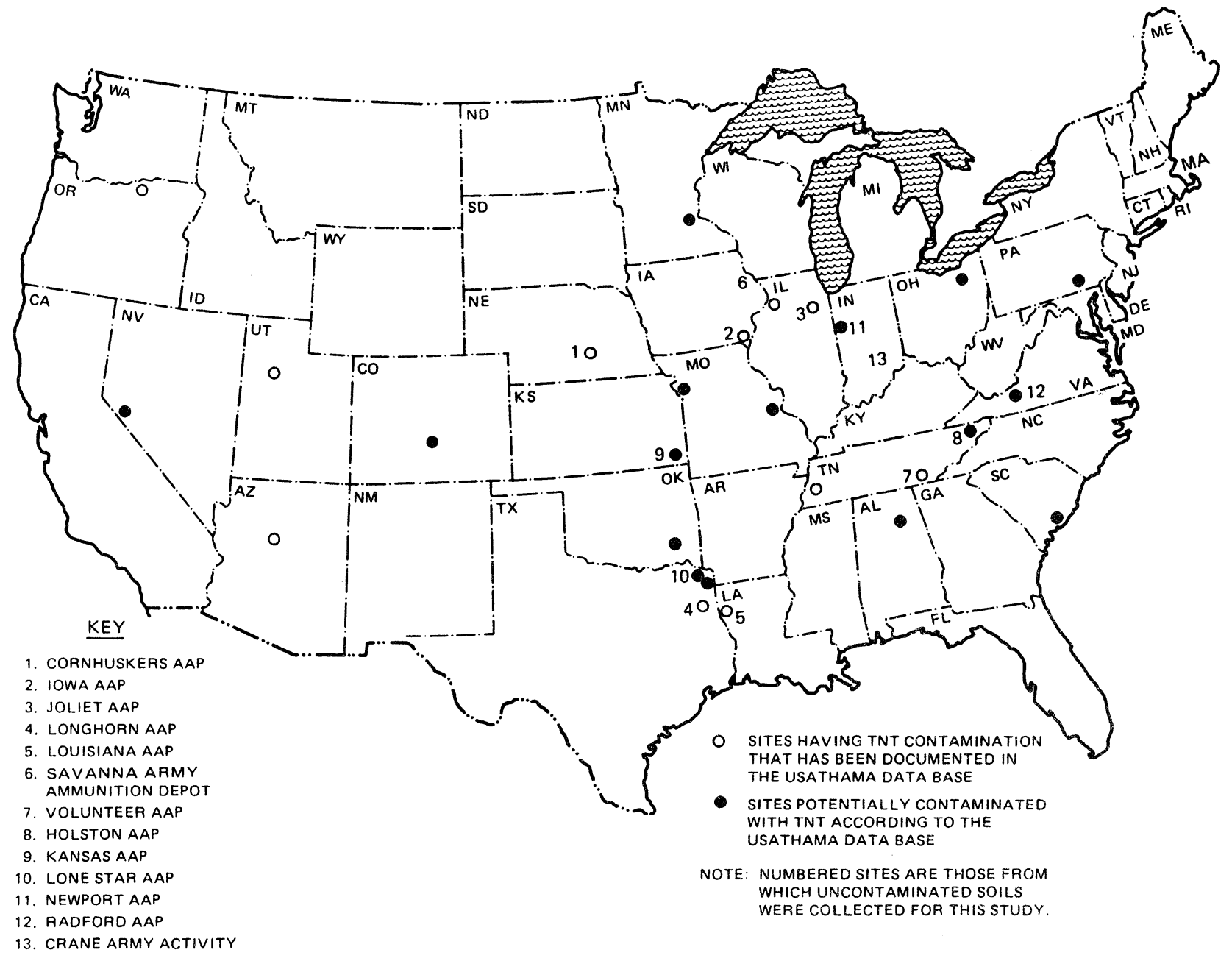

Figure 1. US Army installations having confirmed or potential TNT contamination (adapted from Tucker et al. 1985) 
7. Sampling of soils from all of the AAPs of interest was precluded by budget limitations. Many of the locations were selected because travel by personnel of the US Army Engineer Waterways Experiment Station (WES) for other purposes was to proximal areas. However, a special trip was made to Radford AAP, Radford, Va., because it is the only facility currently manufacturing TNT. Holston AAP was sampled on the same trip since it was within practical driving distance of Radford. A special trip was also made to Louisiana, Longhorn, and Lone Star AAPs because they are very close together and within easy driving distance of WES.

8. Soil survey maps for each of the AAPs to be sampled were obtained from local US Department of Agriculture Soil Conservation Service (SCS) offices. The SCS, in most sampling areas of the country, were preparing new survey maps. Therefore, maps for some areas were not yet updated and were very old. One county of interest had no map available. Soil maps were taken to the AAP where personnel familiar with the operations and grounds of the facility were asked to identify areas potentially receiving TNT contamination from past or present activities. Activities mentioned as potential causes of contamination included dumping, burning, or lagoonal disposal of manufacturing effluents or wash waters from load and pack operations. Soil type in potentially contaminated areas was noted on the soil survey map, and areas on the facility having the same soil type, but safely removed from any possible contamination, were located. Test samples were taken from these uncontaminated sites.

9. Soil samples were taken by removing any vegetative cover or litter from the soil surface and collecting several shovelfuls from the top $15 \mathrm{~cm}$ of soll (the A horizon). The same procedure was followed at several spots within a few metres of each other to obtain a representative soil sample. Approximately 40 \& of soil was collected from each AAP.

10. All soils were allowed to air dry, ground to pass through a 2-mm sieve, sealed, and stored at $25^{\circ} \mathrm{C}$ in $28-\ell$ Bain Marie buckets until tested.

\section{Physical and Chemical Characterization of Soils}

$\underline{\mathrm{pH}}$

11. Four 10-g replicates of soil (oven dry weight (ODW) basis) were weighed to the nearest $0.1 \mathrm{mg}$ into $50-\mathrm{ml}$ glass beakers. The soil samples were 
mixed with $20 \mathrm{ml}$ of reverse osmosis (RO) water until all dry particles were thoroughly wet. The resulting suspension was stirred with a magnetic stirrer for 1 min every 15 min until a total of $45 \mathrm{~min}$ had passed. The $\mathrm{pH}$ of the suspension was then determined with a glass and a reference silver-silver chloride electrode on a Beckman Model SS-3 pH meter (Beckman Instruments, Inc., Fullerton, Calif.).

Particle size distribution

12. The particle size distribution was determined in four replicates by using the method of Day (1956) as modified by Patrick (1958). The method determines the percentage of three size fractions in the soil: sand (2 $\mathrm{mm}$ to $50 \mu$ diameter), silt (50 to $2 \mu$ diameter), and clay ( $<2 \mu$ diameter). Cation exchange capacity

13. Cation exchange capacity (CEC) was determined in four replicates using the ammonium saturation method of Schollenberger and Simon (1945). Electrical conductivity

14. Electrical conductivity (EC) was determined in four replicates on extracts of saturated pastes made from soils using the method of Rhoades (1982). The conductivity meter used was a Model 31 YSI (Yellow Springs Instrument Company, Yellow Springs, Ohio).

Extractable iron, manganese, aluminum, and calcium

15. An ammonium oxalate/oxalic acid extraction procedure was used to remove hydroxides of iron, manganese, aluminum, and calcium from soils in four replicates (Brannon and Patrick 1985). Extracts were analyzed by the Analytical Laboratory Group, Environmental Laboratory, WES, using a Beckman Spectra Span IIIB Argon Plasma Emission Spectrophotometer (Applied Research Laboratories, Dearborn, Mich.). Percent organic carbon

16. Percent organic carbon (OC) was determined by the complete combustion method described by Nelson and Sommers (1982).

\section{Soil to Solution Ratio}

17. To compare results of tests conducted with different soil to solution ratios, adsorption of TNT using four soil to solution ratios was compared. Since both organic and inorganic surfaces potentially provide sites 
for adsorption, and organic carbon is of ten highly correlated with adsorption of neutral organic compounds, e.g., pesticides (Weed and Weber 1974), a soil high in percent $O C$ and also relatively high in $C E C$ and percent clay was selected. Joliet AAP soil, the soil selected, exhibited the highest percent OC of any of the AAP soils (3.592 percent) and also exhibited a relatively high CEC (102) and percent clay (23.8). The four ratios tested were 1 to 5 , 1 to 10,1 to 20 , and 1 to 30 .

18. Soil samples of $5,2.5,1.25$, and $0.83 \mathrm{~g}$ were weighed (ODW) into 50-m1 stainless steel centrifuge tubes in three replicates. To each tube were added $25 \mathrm{ml}$ of a $\left[{ }^{14} \mathrm{C}\right] \mathrm{TNT}$ solution containing $0.023 \mu \mathrm{Ci}{ }^{14} \mathrm{C} / \mathrm{ml}$ and $16 \mu \mathrm{g}$ total $\left({ }^{14} \mathrm{C}\right.$ labeled plus unlabeled) $\mathrm{TNT} / \mathrm{m} 1$. Tubes were sealed and placed on a reciprocating box shaker at highest speed (280 excursions/minute) for $2 \mathrm{hr}$. After shaking, the tubes were centrifuged for $20 \mathrm{~min}$ at $17,369 \times$ gravity $(12,000 \mathrm{rpm})$. Three $1-\mathrm{ml}$ aliquots of the solution were removed to each of three vials containing $20 \mathrm{ml}$ of PCS liquid scintillation cocktail (Amersham Corporation, Arlington Heights, I11॰) and counted for $20 \mathrm{~min}$ in a Beckman LS-100 Liquid Scintillation System (LS) (Beckman Instruments, Inc., Fullerton, Calif.). The LS was equipped with a plug-in, fixed, optimum window module for counting ${ }^{14} \mathrm{C}$ and an external reference standard module $\left({ }^{137} \mathrm{Ce}\right)$. Standard curves were prepared by plotting counts per minute per millilitre against micrograms of TNT per millilitre in the $\left[{ }^{14} \mathrm{C}\right]$ TNT treatment solution. Micrograms of TNT per millilitre of solution were then related to micrograms per gram of soil (ODW).

\section{Adsorption Kinetics}

19. Adsorption kinetics were determined using soils from two of the AAPs. The two soils, selected on the basis of percent OC, were the Louisiana AAP soil, with a relatively low percent OC $(0.367)$, and the Joliet AAP soil, with a relatively high percent OC (3.592). Each soil was equilibrated with three concentrations of $\left[{ }^{14} \mathrm{C}\right] \mathrm{TNT}$ in aqueous solution $(1.0,4.0$, and $16.0 \mu \mathrm{g}$ $\mathrm{TNT} / \mathrm{m} 1$ ) . Concentration values included both ${ }^{14} \mathrm{C}$-labeled and unlabeled TNT. These concentrations were equivalent to $5.0,20.0$, and $80.0 \mu \mathrm{g} \mathrm{TNT} / \mathrm{g}$ of soil in the centrifuge tubes. Each solution also contained $0.027 \mu \mathrm{Ci} / \mathrm{ml}$ of ${ }^{14} \mathrm{C}$-labeled TNT. Five-gram soil samples were weighed into 50-ml stainless steel centrifuge tubes in three replicates for each sampling time. Then, 
$25 \mathrm{ml}$ of $\left[{ }^{14} \mathrm{C}\right] \mathrm{TNT}$ solution was added to each tube. The tubes were placed on a reciprocating box shaker and allowed to shake at highest speed. Three tubes were removed at each of the following times: $0.25,0.50,1.00,1.50,2.00$, $5.00,10.00$, and $24.00 \mathrm{hr}$. As soon as tubes were removed, they were centrifuged for $30 \mathrm{~min}$ at $17,369 \times$ gravity. Three $1-\mathrm{ml}$ aliquots of the supernatant were counted by LS for $10 \mathrm{~min}$. Zero time values were determined by counting $1 \mathrm{ml}$ of solution from each concentration of TNT in three replicates.

20. Three replicates of each test solution containing no soil were placed on the shaker and sampled initially and at 2.00 and $24.00 \mathrm{hr}$. These "no-soil" blanks were included to measure any adsorption of $\left[{ }^{14} \mathrm{C}\right] \mathrm{TNT}$ to the walls of the centrifuge tubes.

21. A standard curve relating ${ }^{14} \mathrm{C}$ counts per minute per millilitre to concentration of TNT (micrograms per millilitre) was prepared for each test solution (Appendix A). The TNT concentration in the solution phase, assuming that all ${ }^{14} \mathrm{C}$ activity was due to $\left[{ }^{14} \mathrm{C}\right] \mathrm{TNT}$ and not to decomposition products, was plotted against time to establish an adsorption kinetics curve for each of the soils.

\section{Desorption Kinetics}

22. For comparative purposes, the same soils selected for the adsorption kinetics studies were also used for the desorption kinetics studies. Eighteen 1-g samples (ODW) of Joliet and Louisiana AAP soils were weighed to the nearest $0.1 \mathrm{mg}$ into 50-ml Oak Ridge Type polycarbonate centrifuge tubes (Sybron/Nalge, Rochester, N. Y.). Twenty millilitres of the $16-\mu g / m l\left[{ }^{14} \mathrm{C}\right] \mathrm{TNT}$ solution was added to all tubes, the tubes were weighed to the nearest $0.01 \mathrm{~g}$, and the soils adsorbed for $2 \mathrm{hr}$ as described above. Three replicates containing no soil were run as described above to measure any adsorption of $\left[{ }^{14} \mathrm{C}\right] \mathrm{TNT}$ to the polycarbonate centrifuge tubes. After adsorption, tubes were centrifuged, the TNT solution was removed, and the tubes were brought back to original weight by the addition of RO water. All tubes were returned to the reciprocating box shaker. Three tubes of each soil type were removed at each of the following times: $0.5,1.0,1.5,2.0,5.0$, and $10.0 \mathrm{hr}$.

23. Tubes were centrifuged for 20 min at $17,369 \times$ gravity as soon as they were taken from the shaker. One millilitre of solution was removed for scintillation counting, as described for the adsorption test. The TNT 
concentration in the solution phase was plotted against time to establish a desorption kinetics curve for each of the soils.

\section{Batch Adsorption Equilibrium}

24. One-gram soil samples (ODW) from each of the AAPs, plus a Tunica silt and a Sharkey clay, were weighed to the nearest $0.001 \mathrm{~g}$ into $50-\mathrm{ml}$ polycarbonate centrifuge tubes in three replicates for each of the following five concentrations of TNT: $1.0,4.0,8.0,12.0$, and $16.0 \mu \mathrm{g} / \mathrm{ml}$. Twenty milli-

litres of $\left[{ }^{14} \mathrm{C}\right] \mathrm{TNT}$ solution containing $0.023 \mu \mathrm{C} 1\left[{ }^{14} \mathrm{C}\right] \mathrm{TNT} / \mathrm{m} 1$, plus sufficient unlabeled TNT to produce the final concentrations listed above, was added to each tube. All tubes were equilibrated for $2 \mathrm{hr}$ on a reciprocating box shaker operated at maximum speed. At the end of the 2-hr period, tubes were centrifuged at $17,369 \times$ gravity for $20 \mathrm{~min}$. A $1-\mathrm{ml}$ aliquot of the solution phase was removed and counted three times by LS for $10 \mathrm{~min}$.

\section{Sequential Desorption}

25. Eight soils selected on the basis of average adsorption coefficients (soil concentration/solution concentration), or $\mathrm{K}_{\mathrm{d}}$ values, were used in the sequential desorption tests. Soils exhibiting as broad a range in adsorption as possible were selected. Twenty millilitres of $16-\mu \mathrm{g} T \mathrm{TN} / \mathrm{ml}$ solution was added to tubes containing $0.001 \mathrm{~g}$ of each of the selected soils, and each tube was weighed to the nearest $0.01 \mathrm{~g}$. After $2 \mathrm{hr}$ of adsorption, the solution was removed, and the tubes were brought up to the original weight with RO water. They were returned to the reciprocating box shaker for $2 \mathrm{hr}$. At the end of the first desorption cycle, the tubes were centrifuged for 10 min at $17,369 \times$ gravity and the solution removed. One millilitre of the solution was diluted with $20 \mathrm{ml}$ of PCS and counted by LS for $10 \mathrm{~min}$ three times. Second and third desorption cycles were conducted in the same manner. A standard curve was consulted to convert counts per minute/millilitre to micrograms TNT/millilitre (Appendix A). 


\section{Soil Characterization}

26. Results of the soil characterization tests are given in Table 1. In general, the AAP soils represented a wide range in soil characteristics. Percent $O C, C E C$, and percent clay were relatively low, but not atypical of soils in the eastern and central United States (Buckman and Brady 1969).

\section{Soil to Solution Ratio}

27. Adsorption coefficients for each soil to solution ratio are tabulated below. Analysis of variance showed significant differences among the $\mathrm{K}_{\mathrm{d}}$ values for the ratios tested. Use of the Waller-Duncan K-Ratio Test for separating differences between means showed a significant difference between all ratios except the $1: 20$ and the $1: 30(P=0.05)$. The $K_{d}$ value decreased as the ratio increased. It was desirable to correlate results of this study with results of a study of the effects of redox potential on adsorption and desorption of TNT. In the second study it was necessary to maintain an aqueous suspension of soil. The soil to solution ratio that could be most effectively suspended was 1:20. Therefore, the 1:20 ratio was selected for a11 subsequent tests.

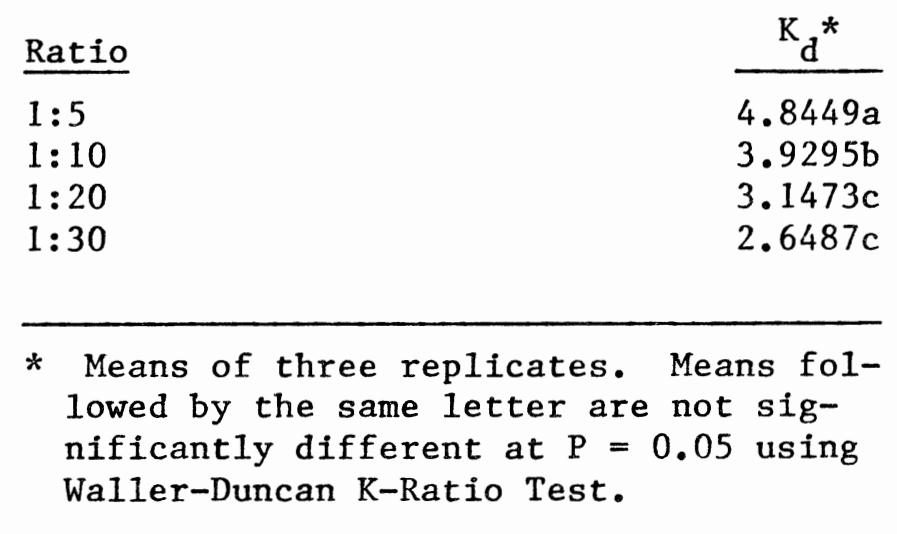

\section{Adsorption Kinetics}

28. Graphs of adsorption kinetics for Joliet and Louisiana AAP soils with three concentrations of TNT are shown in Figures 2 and 3, respectively. 
Table 1

Chemical and Physical Characteristics of Army Ammunition Plant Soils*

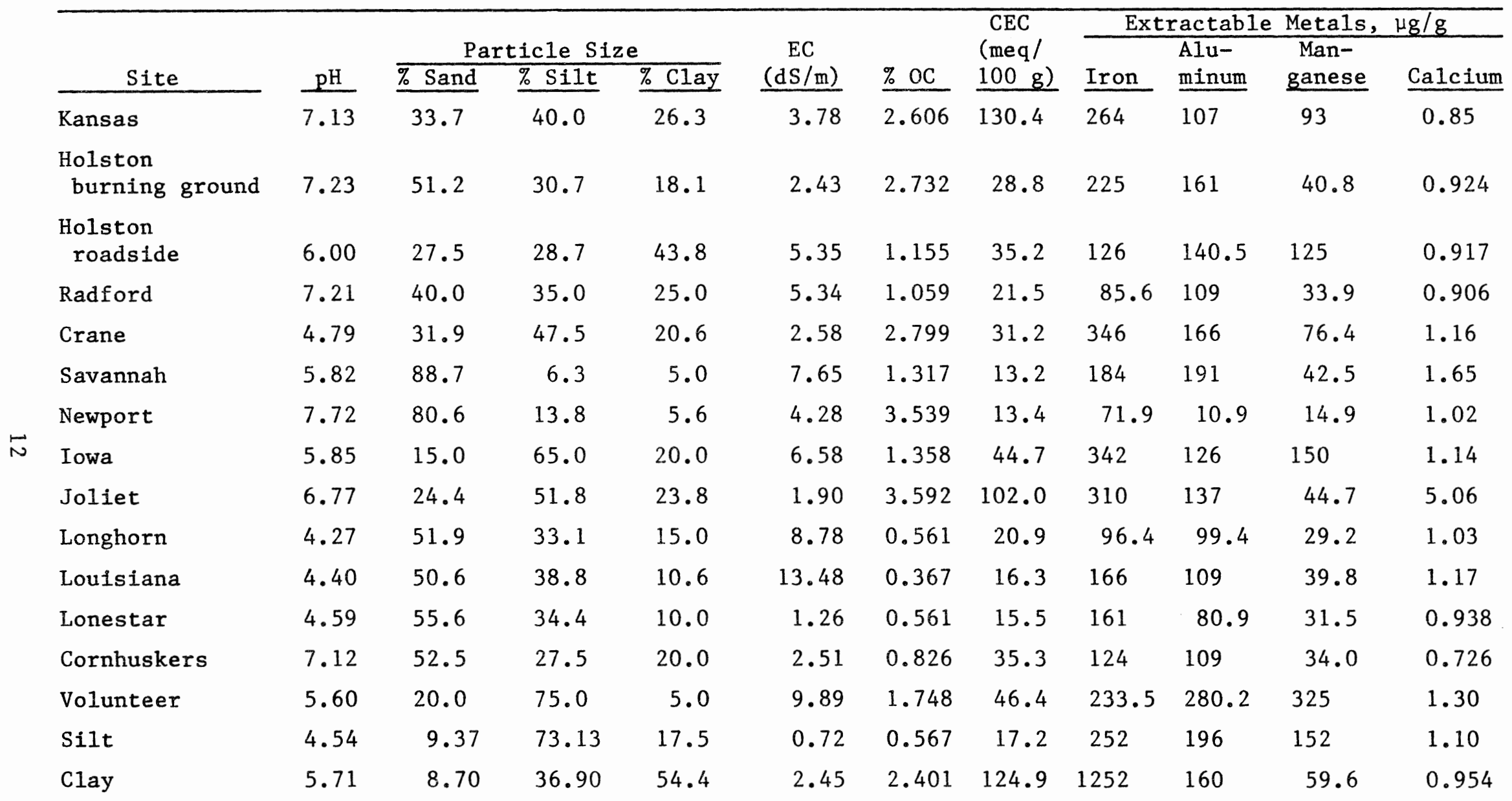

* Values given are means of four replicates. 


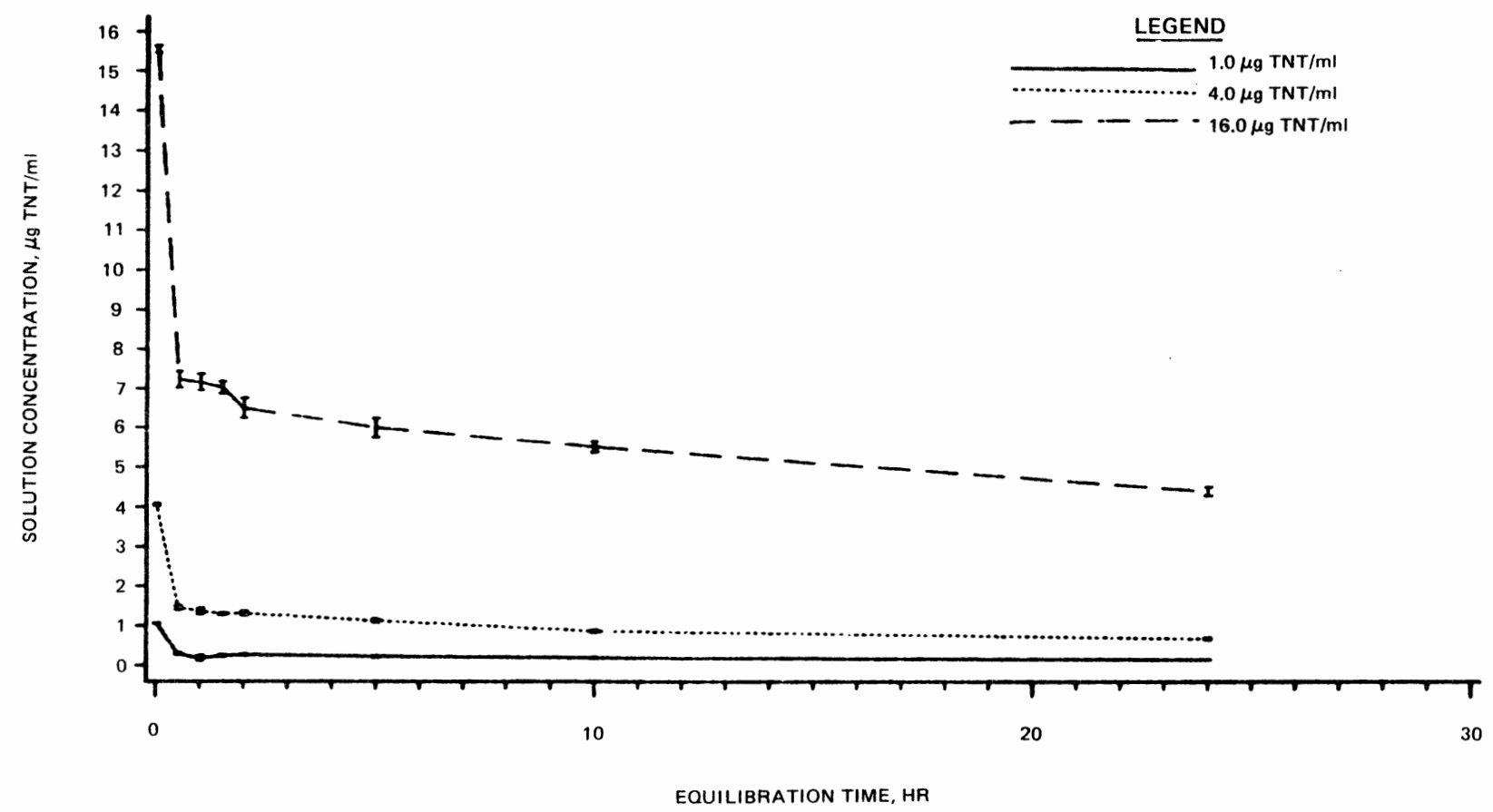

Figure 2. Adsorption kinetics curves for TNT in soil from Joliet AAP using three concentrations of TNT in aqueous solution. (Vertical bars represent \pm 1 standard deviation unit from the mean)

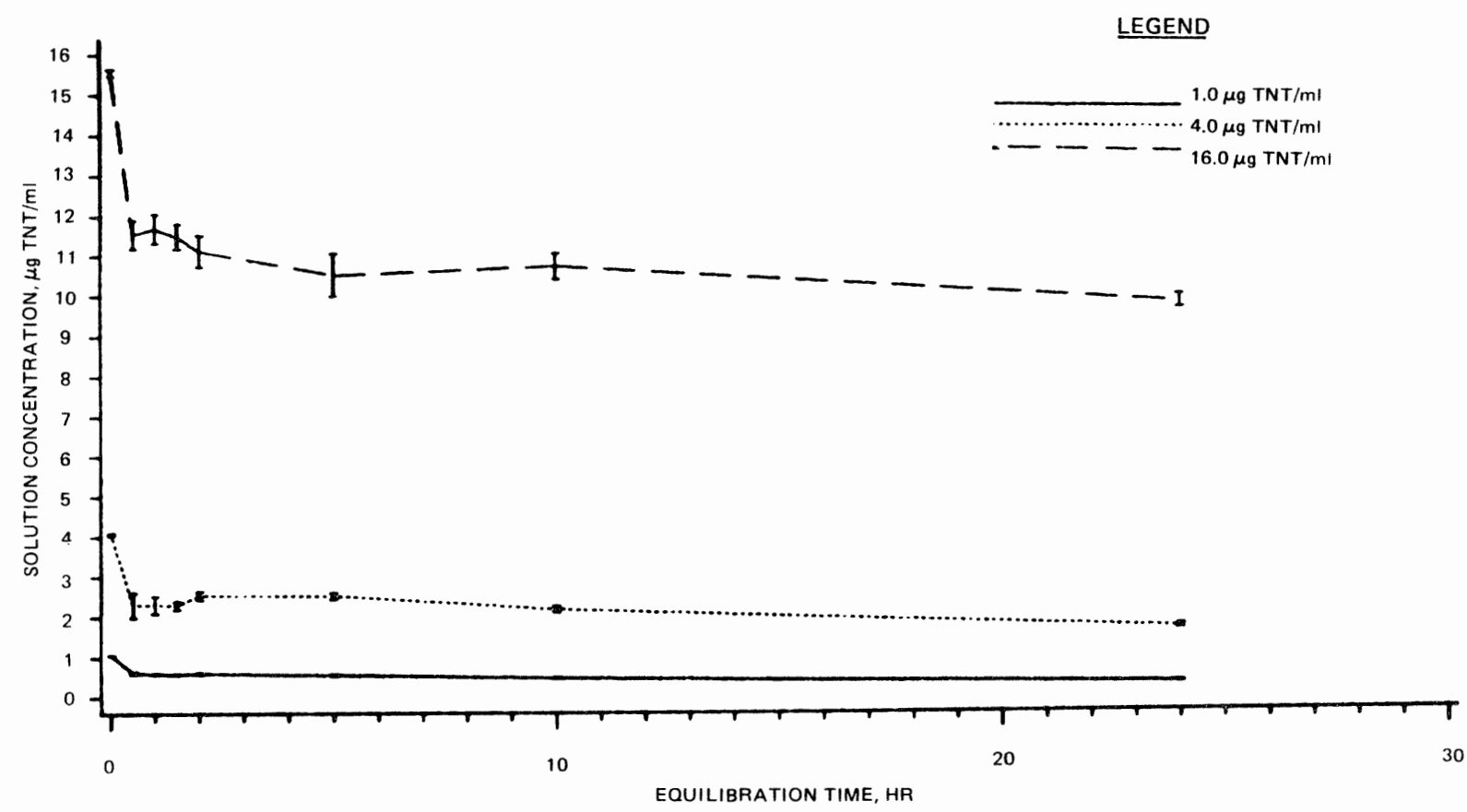

Figure 3. Adsorption kinetics curves for TNT in soil from Louisiana AAP using three concentrations of TNT in aqueous solution. (Vertical bars represent \pm 1 standard deviation unit from the mean) 
Adsorption occurred rapidly. Joliet AAP soil reached a steady state (no statistically significant change in solution concentration) within $1.0 \mathrm{hr}$. More than half of the TNT was adsorbed within the first hour from all three test solutions. After $2 \mathrm{hr}$, the solution concentration began to decrease again. A similar decrease was reported by Tucker et al. (1985), who followed the adsorption kinetics of TNT in soil by high performance liquid chromatography of extracts of the solution phase. They attributed this decrease in solution concentration after reaching a temporary steady state to microbial degradation of TNT in the soil phase. Their conclusion was supported by the presence of microbial degradation products in the solution phase. If degradation products are formed, a decrease in solution ${ }^{14} \mathrm{C}$ counts may be due to a shift in the partitioning (equilibrium) caused by the difference between adsorption of TNT and adsorption of the product or products being formed.

29. The Louisiana AAP soil reached a steady state within $0.5 \mathrm{hr}$ and maintained the steady state for at least $2 \mathrm{hr}$ at all tested concentrations of TNT. A decrease in solution concentration similar to the decrease observed in the Joliet AAP soil was observed after $2 \mathrm{hr}$ in the Louisiana AAP soil. However, the decrease proceeded more slowly in the Louisiana AAP soil. It is possible that the higher OC content of the Joliet AAP soil increased the rate of microbial degradation by providing substrate for the microorganisms. Several investigators (Osmon and Klausmeier 1972; Klausmeier, Osmon, and Hoffsommer 1973; Won et al. 1974) have found that although TNT cannot act as the sole carbon source for microorganisms, degradation of TNT can proceed in the presence of other carbon sources.

\section{Desorption Kinetics}

30. Desorption kinetics curves for Joliet and Louisiana AAP soils are presented in Figures 4 and 5, respectively. Joliet AAP soil reached a steady state in $1.5 \mathrm{hr}$, and Louisiana AAP soil reached a steady state in $2 \mathrm{hr}$. These results indicate that desorption occurs almost as rapidly as adsorption. From 2 to $10 \mathrm{hr}$, no significant change in the concentration of TNT in the solutions was observed. When a steady state of desorption was reached, Joliet AAP soil still retained an average of 12.5 percent $(2.0 \mu \mathrm{g} \mathrm{TNT} / \mathrm{ml})$ of the added TNT; Louisiana AAP soil retained 6.25 percent $(1.0 \mu \mathrm{g} / \mathrm{ml})$. 


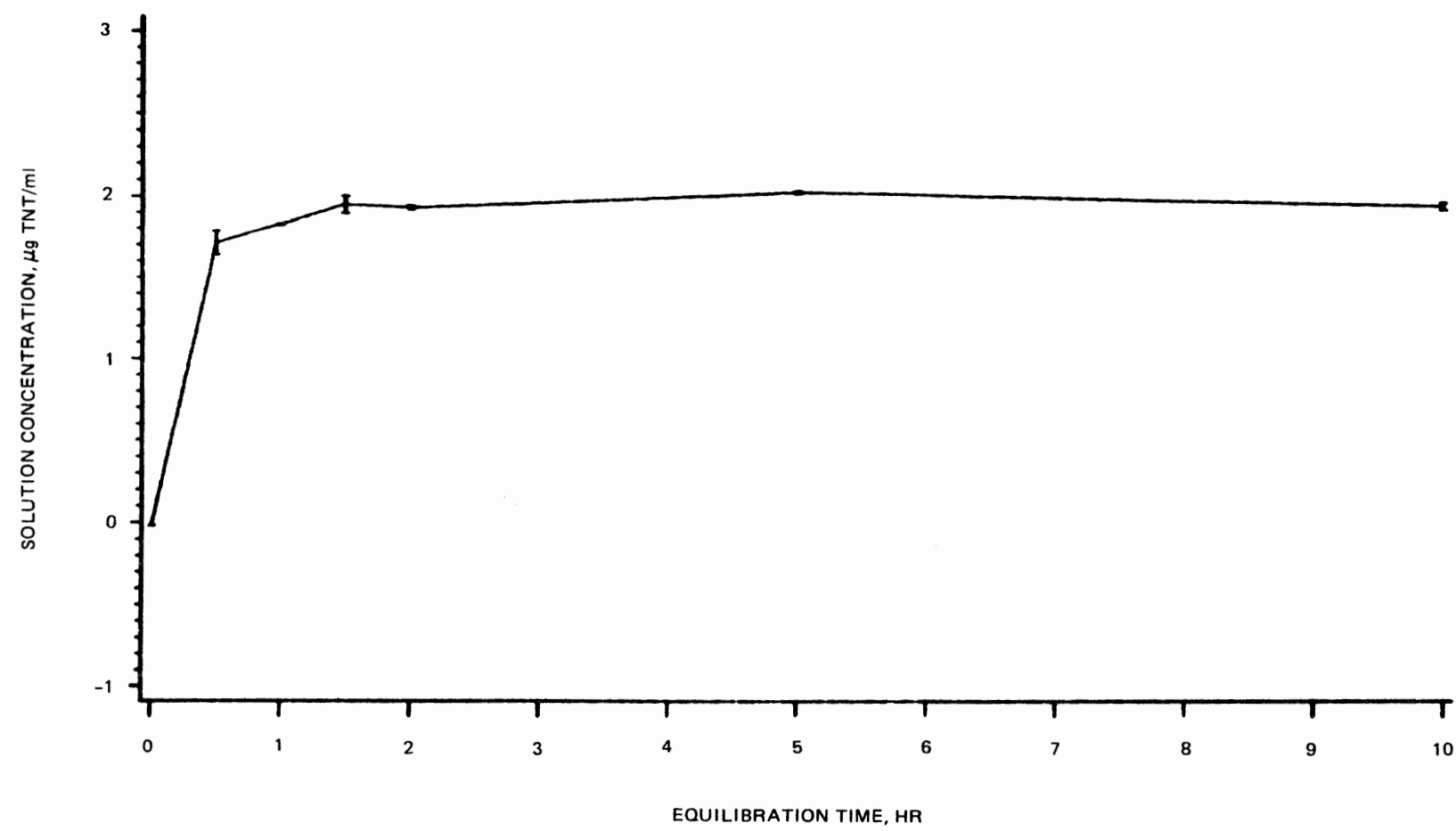

Figure 4. Desorption kinetics for TNT in soil from Joliet AAP. (Vertical bars represent \pm 1 standard deviation unit from the mean)

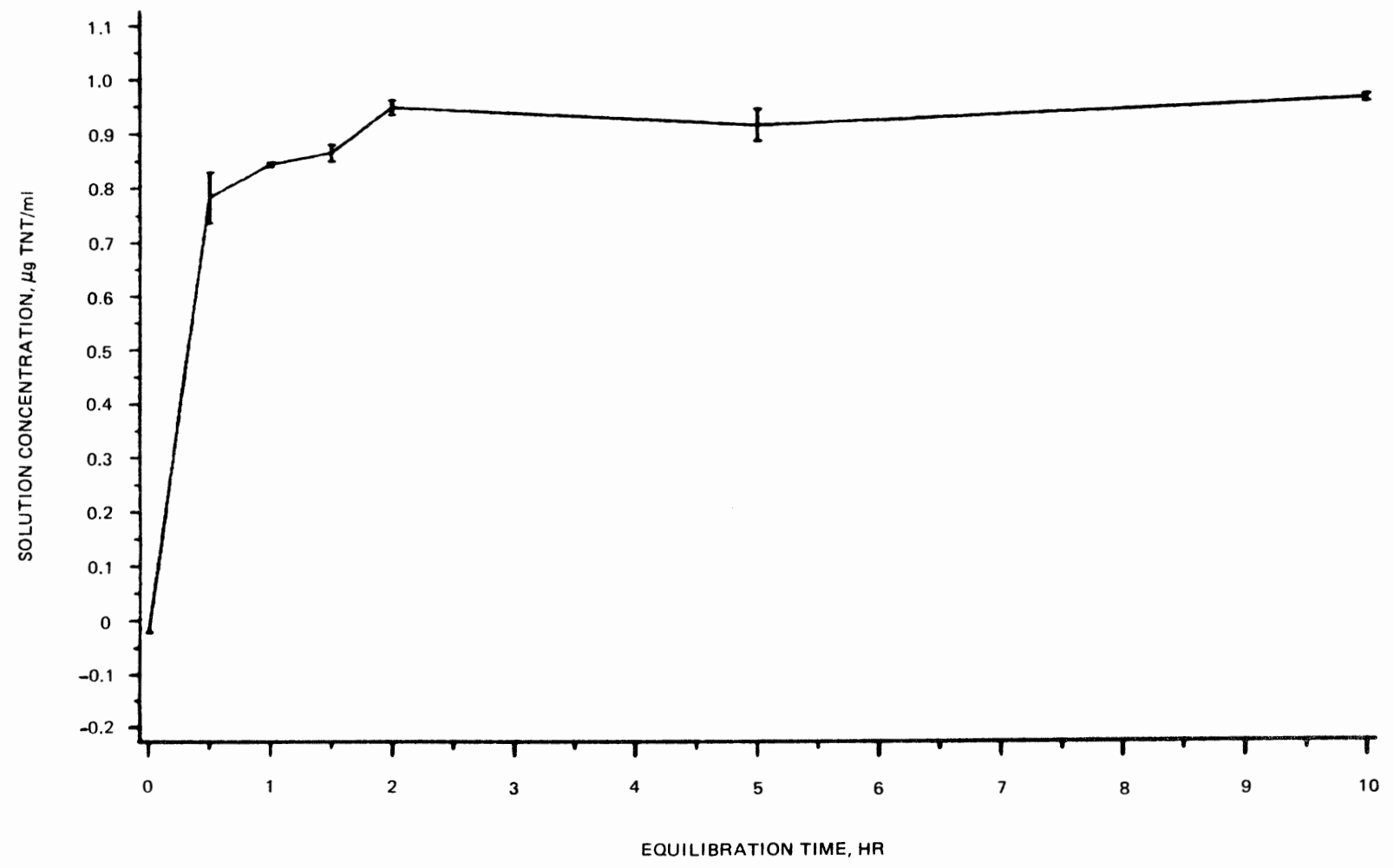

Figure 5. Desorption kinetics for TNT in soil from Louisiana AAP. (Vertical bars represent \pm 1 standard deviation unit from the mean) 
Batch Adsorption Equilibrium and Sequential Desorption

31. Table 2 shows slopes $\left(\mathrm{K}_{\mathrm{d}}\right)$ and statistical information on adsorption results from each $\mathrm{AAP}$ soil, as well as from the clay and silt. Adsorption isotherms were linear up to the highest concentration of TNT used (16.0 $\mathrm{\mu g}$ $\mathrm{TNT} / \mathrm{ml}$ ) (Figure 6). At that point, each curve leveled off, indicating that maximum adsorption (saturation with respect to TNT under the conditions of the test) had been reached at the previous point $(12.0 \mu \mathrm{g} T \mathrm{TN} / \mathrm{ml})$ or between the highest two concentrations (12.0 and $16.0 \mu \mathrm{g}$ TNT/mI). Figure 7 shows a typical isotherm (the isotherm for Joliet AAP soil), omitting points for the highest concentration in order to remain in the linear portion of the adsorption isotherm.

32. Table 2 also shows slopes and statistical information for results of sequential desorption of TNT from seven of the AAP soils and from the clay. As illustrated in Figure 8, sequential desorption isotherms were linear. Statistical analyses comparing differences between the slopes of the adsorption and desorption isotherms for each soil type (difference between two independent regressions, Steel and Torrie 1980) showed no significant differences at the 0.05 level of probability. This result is an indication of absence of hysteresis, 1.e., adsorption and desorption occurred to the same extent.

33. Table 3 shows the amounts of TNT adsorbed and desorbed for each soil tested. Even after three sequential desorption cycles, some TNT remained in the soils.

34. Results of a Pearson correlation analysis of adsorption $K_{d}$ values with soil properties are presented in the tabulation below. Adsorption was most closely correlated with CEC $(R=0.88)$ and extractable iron $(R=0.88)$. These results suggest that TNT and/or its degradation products can occupy CEC sites on the clay. It is possible that correlation with percent $O C$ would have been higher if levels of $O C$ had been tigher in the soils.

\begin{tabular}{|c|c|c|c|}
\hline Soil Property & $\mathbf{R}$ & Soll Property & $\mathrm{R}$ \\
\hline CEC & 0.88545 & $\mathrm{pH}$ & 0.17112 \\
\hline Iron & 0.88103 & Percent silt & 0.16353 \\
\hline Percent clay & 0.68884 & Manganese & 0.03835 \\
\hline Percent OC & 0.41512 & EC & -0.38611 \\
\hline Calcium & 0.40363 & Percent sand & -0.53870 \\
\hline Aluminum & 0.17287 & & \\
\hline
\end{tabular}


Table 2

Adsorption and Desorption of TNT on Army Ammunition Plant Soils*

\begin{tabular}{|c|c|c|c|c|c|c|c|c|}
\hline \multirow[b]{2}{*}{ Soil } & \multicolumn{4}{|c|}{ Adsorption } & \multicolumn{4}{|c|}{ Desorption } \\
\hline & Slope $\left(\mathrm{K}_{\mathrm{d}}\right)$ & $\begin{array}{c}\text { Standard } \\
\text { Error }\end{array}$ & $\mathrm{R}^{2}$ & $\underline{\mathrm{PR}>\mathrm{F}}$ & Slope $\left(K_{d}\right)$ & $\begin{array}{c}\text { Standard } \\
\text { Error } \\
\end{array}$ & $\mathrm{R}^{2}$ & $\mathrm{PR}>\mathrm{F}$ \\
\hline Clay & $11.298 a$ & 0.6344 & 0.9694 & 0.0001 & $9.5949 a$ & 0.2084 & 0.9967 & 0.0001 \\
\hline Silt & 2.8111 & 0.3222 & 0.8839 & 0.0001 & & & & \\
\hline Cornhuskers & 4.001 & 0.3332 & 0.9356 & 0.0001 & & & & \\
\hline Crane & $3.900 a$ & 0.3404 & 0.9292 & 0.0001 & $5.2793 a$ & 1.1877 & 0.7384 & 0.003 \\
\hline $\begin{array}{l}\text { Holston } \\
\text { burning ground }\end{array}$ & 4.116 & 0.4031 & 0.9125 & 0.0001 & & & & \\
\hline $\begin{array}{l}\text { Holston } \\
\text { roadside }\end{array}$ & 3.2682 & 0.2395 & 0.949 & 0.0001 & & & & \\
\hline Iowa & $5.1165 a$ & 0.4439 & 0.93 & 0.0001 & $6.8707 a$ & 0.4261 & 0.9738 & 0.0001 \\
\hline Joliet & $7.2725 a$ & 0.3716 & 0.9746 & 0.0001 & $7.6672 a$ & 0.5502 & 0.9652 & 0.0001 \\
\hline Kansas & $6.2686 a$ & 0.3104 & 0.9761 & 0.0001 & $6.4444 a$ & 0.338 & 0.9811 & 0.0001 \\
\hline Lonestar & 2.543 & 0.3107 & 0.8701 & 0.0001 & & & & \\
\hline Longhorn & 3.7292 & 0.3247 & 0.9296 & 0.0001 & & & & \\
\hline Louisiana & 2.7377 & 0.276 & 0.9077 & 0.0001 & & & & \\
\hline Newport & $2.4413 a$ & 0.2693 & 0.8915 & 0.0001 & $4.0129 a$ & 1.1518 & 0.6342 & 0.0102 \\
\hline Radford & $3.4415 a$ & 0.2927 & 0.9325 & 0.0001 & $4.7804 a$ & 1.5168 & 0.5866 & 0.0161 \\
\hline Savanna & $3.0911 \mathrm{a}$ & 0.2026 & 0.9588 & 0.0001 & $4.7082 a$ & 0.5387 & 0.9161 & 0.0001 \\
\hline
\end{tabular}

\footnotetext{
* Slopes followed by the same letter within soil type across are not significantly different at the $P=$
} 0.05 level. Values represent means of three replicates. 


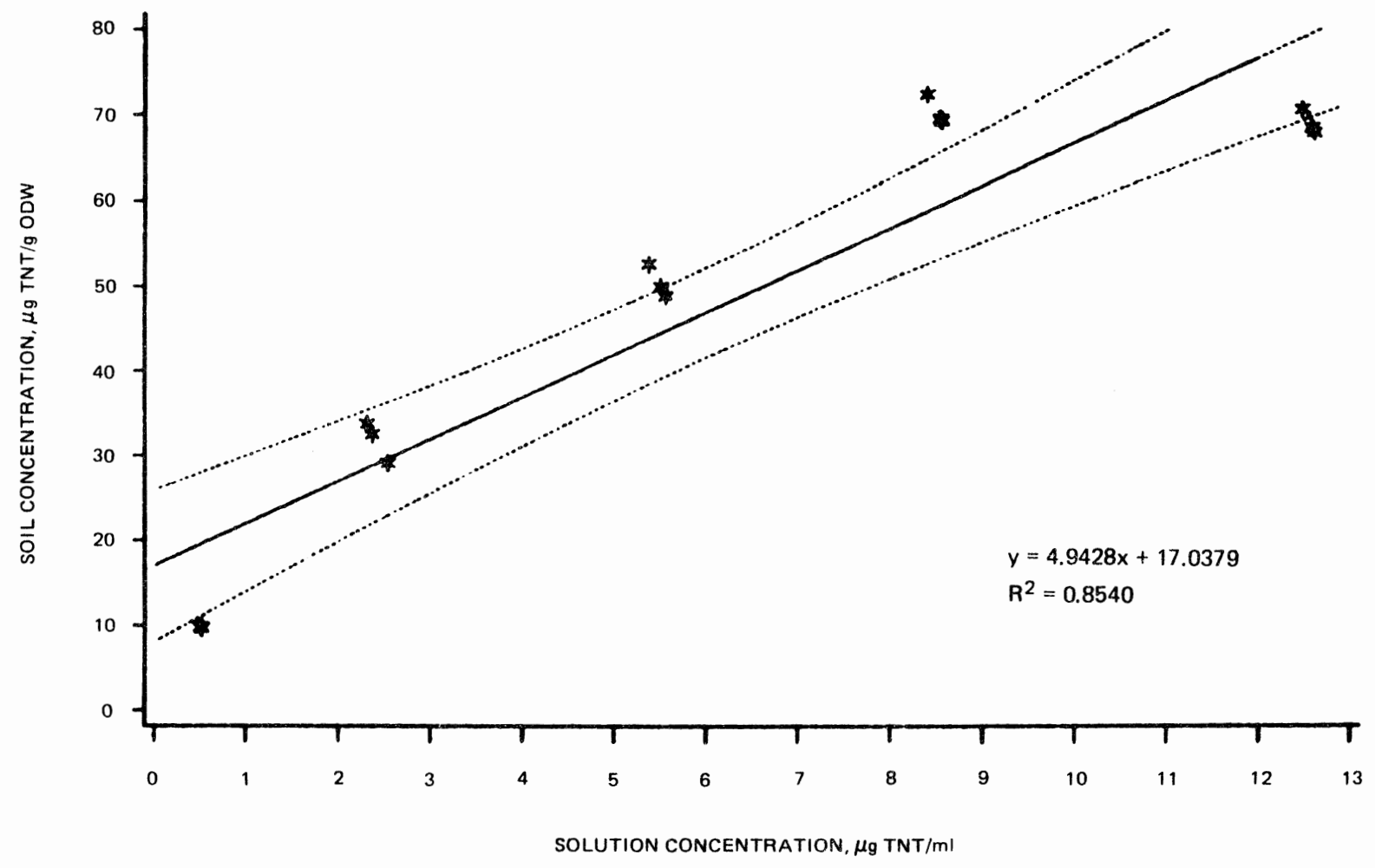

Figure 6. Adsorption isotherm for soil from Joliet AAP illustrating linearity of adsorption up to $12.0 \mu \mathrm{g} \mathrm{TNT} / \mathrm{ml}$ of solution. The $16-\mu \mathrm{g}$ $\mathrm{TNT} / \mathrm{ml}$ solution exhibits no additional adsorption because the soil has become saturated with respect to TNT. Dotted lines mark the limits of the 95-percent confidence interval 


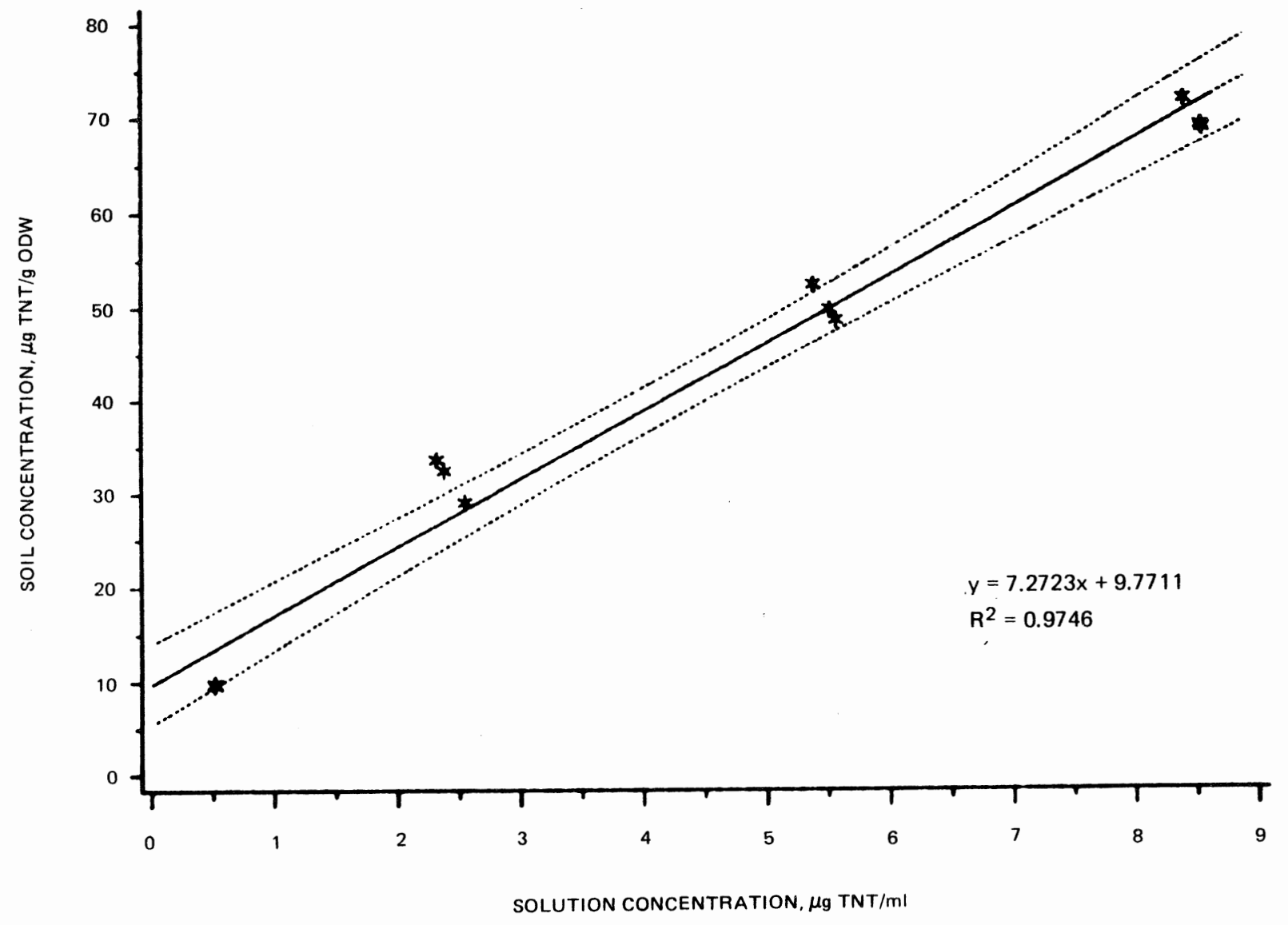

Figure 7. Adsorption isotherm for Joliet AAP soil, showing only the linear portion of the curve (the $16.0-\mu \mathrm{g} T \mathrm{TN} / \mathrm{ml}$ data point omitted). This curve is typical of adsorption isotherms for all the tested AAP soils. (See Table 2 for slopes of all other adsorption isotherms.) Dotted lines mark the limits of the 95-percent confidence interval 


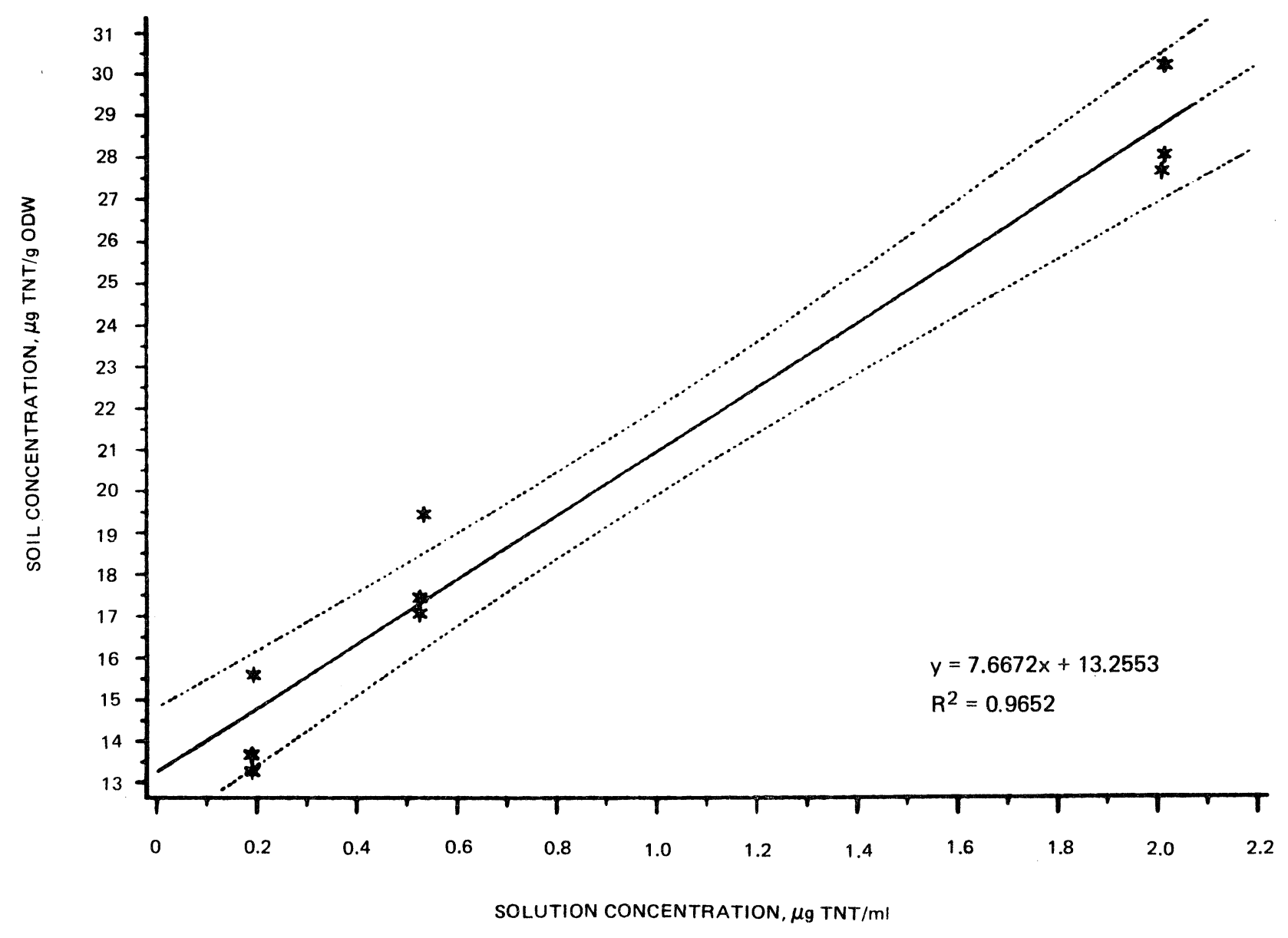

Figure 8. Sequential desorption isotherm for Joliet AAP soil. This curve is typical of desorption isotherms for all of the tested AAP soils. (See Table 2 for slopes of all other AAP soils for which sequential desorption was performed.) Dotted lines mark the limits of the 95-percent confidence interval 
Table 3

TNT Adsorbed and Desorbed by AAP Soils

\begin{tabular}{|c|c|c|c|c|}
\hline \multirow[b]{2}{*}{ Soil } & \multicolumn{2}{|c|}{ TNT Adsorbed } & \multicolumn{2}{|c|}{$\begin{array}{l}\text { TNT Remaining in Soil } \\
\text { After Three Sequential } \\
\text { Desorption Cycles }\end{array}$} \\
\hline & $\mu \mathrm{g} / \mathrm{g}$ & $\begin{array}{l}\text { Percent of Total } \\
\text { TNT Added } \\
\end{array}$ & $\mu \mathrm{g} / \mathrm{g}$ & $\begin{array}{c}\text { Percent of } \\
\text { Total Adsorbed } \\
\end{array}$ \\
\hline Crane & 41.08 & 12.84 & 4.50 & 10.95 \\
\hline Iowa & 55.89 & 17.46 & 6.85 & 12.26 \\
\hline Joliet & 68.81 & 21.50 & 13.26 & 19.27 \\
\hline Kansas & 60.06 & 18.77 & 6.61 & 11.01 \\
\hline Newport & 23.95 & 7.48 & 1.78 & 7.43 \\
\hline Radford & 34.79 & 10.87 & 4.62 & 13.28 \\
\hline Savanna & 25.93 & 8.10 & 2.02 & 7.79 \\
\hline Clay & 101.73 & 31.79 & 23.78 & 23.38 \\
\hline
\end{tabular}

Environmental Consequences of Adsorption/Desorption Properties of TNT

35. The conditions under which this study was performed were most closely analogous to short-term exposure of soils to aqueous TNT contamination in the environment. Sorption properties of TNT photodecomposition products or microbial degradation products were not taken into account. It is possible that soil sorption properties of these compounds differ from the properties of TNT. In the absence of degradation products, TNT was only slightly resistant to desorption. Almost 20 percent of adsorbed TNT was retained after three sequential desorption cycles of Joliet AAP soil, the soil most recalcitrant to desorption. Other soils retained less than 15 percent. Lack of hysteresis suggests that continued desorption, or leaching, may remove more, and perhaps all, of the TNT from the AAP soils unless more strongly adsorbed degradation products are formed. 


\section{PART IV: CONCLUSIONS}

36. The TNT adsorption and desorption studies resulted in the following conclusions :

a. Soils from the AAPs sampled exhibited a broad range of physical and chemical characteristics. Their relatively low organic carbon and clay content is consistent with low retention of organic contaminants.

b. Adsorption of TNT to the AAP soils was rapid, with the extent of adsorption correlating most highly with CEC, extractable iron, percent clay, and percent organic carbon. Desorption was also fairly rapid, as evidenced by the desorption kinetics curves. Desorption was essentially complete after three sequential desorption cycles. 


\section{REFERENCES}

Brannon, J. M., and Patrick, W. H., Jr. 1985. "Fixation and Mobilization of Antimony in Sediments," Environmental Pollution (Series B), Vo1 9, pp 107-126. Buckman, H. O., and Brady, N. C. 1969. The Nature and Properties of Soils, 7th ed., Macmillan, London.

Cragin, J. H., Leggett, D. C., Foley, B. T., and Schumacher, P. W. 1985. "TNT, RDX, and HMX Explosives in Soils and Sediments: Analysis Techniques and Drying Losses," CRREL Report 85-15, prepared by US Army Engineer Cold Regions Research and Engineering Laboratory, Hanover, N. H., for US Army Toxic and Hazardous Materials Agency, Aberdeen Proving Ground, Md.

Day, P. R. 1956. "Report of the Committee on Physical Analyses, 1954-1955, Soil Science Society of America," Proceedings, Soil Science Society of America, Vol 20, pp 167-169.

Dilley, J. V., Tyson, C. A., and Newe11, G. W. 1978. "Mammalian Toxicological Evaluation of TNT Wastewaters; Vo1 II, Acute and Subacute Mammalian Toxicity of TNT and the LAP Mixture," Contract No. DAMD-17-76-C-6050, US Army Medical Research and Development Command, Washington, DC.

Folsom, B. L., Jr., Teeter, C. L., Barton, M. R., and Bright, J. A. "Plant Uptake of 2,4,6-Trinitrotoluene (TNT)," Miscellaneous Paper in preparation, US Army Engineer Waterways Experiment Station, Vicksburg, Miss.

Kaplan, D. L., and Kaplan, A. M. 1982a. "Mutagenicity of 2,4,6Trinitrotoluene-Surfactant Complexes," Bulletin of Environmental Contamination and Toxicology, Vo1 28, pp 33-38.

- 1982b. "2,4,6-Trinitrotoluene-Surfactant Complexes: Decomposition, Mutagenicity, and Soil Leaching Studies," Environmental Science and Technology, Vol 16, pp 566-571.

Klausmeier, R. E., Osmon, J. L., and Hoffsommer, J. C. 1973. "Metabolic Disposition of 2,4,6-Trinitrotoluene," Applied Microbiology, Vol 27, No. 3, pp 513-516.

Lakings, D. B., and Gan, 0. 1981. "Identification or Development of Chemical Analysis Methods for Plant and Animal Tissues," US Army Armament and Development Command, Englewood, Md.

Leggett, D. C. 1985. "Sorption of Military Explosive Contaminants on Bentonite Drilling Muds," CRREL Report 85-18, prepared by US Army Engineer Cold Regions Research and Engineering Laboratory, Hanover, N. H., for US Army Toxic and Hazardous Materials Agency, Aberdeen Proving Ground, Md.

Liu, D. H. W., Spanggord, R. J., and Bailey, H. C. 1976. "Toxicity of TNT Wastewater (Pink Water) to Aquatic Organisms," Contract DAMD-17-75-5056, US Army Medical Research and Development Command, Washington, DC.

Nay, M. W., Randal1, C. W., and King, P. H. 1974. "Biological Treatability of Trinitrotoluene Manufacturing Wastewater," Journal of Water Pollution Control Federation, Vo1 46, pp 485-497.

Nelson, D. W., and Sommers, L. E. 1982. "Total Carbon, Organic Carbon, and Organic Matter," Methods of Soil Analysis, Part 2 - Chemical and Microbiological Properties, 2d ed., No. 9, American Society of Agronomy, Madison, Wis. 
Osmon, J. L., and Klausmeier, R. E. 1972. "The Microbial Degradation of Explosives," Developments in Industrial Microbiology, Vo1 14, pp 247-252.

Palazzo, A. J., and Leggett, D. C. 1986. "Effect and Disposition of TNT in a Terrestrial Plant," Journal of Environmental Quality, Vo1 15, No. 1, pp 49-52.

Palazzo, A. J., Leggett, D. L., Butler, P. L., Graham, J. H., and Foley, B. T. 1985. "Effect and Disposition of TNT in a Terrestrial Plant and Validation of Analytical Methods," Contract Report, US Army Engineer Cold Regions Research and Engineering Laboratory, Hanover, N. H.

Patrick, W. H., Jr. 1958. "Modification of Method of Particle Size Analysis," Proceedings, Soil Science Society of America, Vol 22, pp 366-367.

Pennington, J. C. "Plant Uptake of 2,4,6-Trinitrotoluene, 4-Aming-2,6Dinitrotoluene, and 2-Amino-4,6-Dinitrotoluene from Soils Using ${ }^{14}$ C-Labeled and Unlabeled Compounds," Miscellaneous Paper in preparation, US Army Engineer Waterways Experiment Station, Vicksburg, Miss.

Rhoades, J. D. 1982. "Soluble Salts," Methods of Soil Analysis, Part 2 Chemical and Microbiological Properties, 2d ed., No. 9, American Society of Agronomy, Madison, Wis.

Schollenberger, L. J., and Simon, R. H. 1945. "Determination of Exchange Capacity and Exchangeable Bases in Soil-Ammonium Acetate Method," Soil Science, Vo1 9, pp 13-25.

Schott, C. D., and Worthley, E. G. 1974. "The Toxicity of TNT and Related Wastes to an Aquatic Flowering Plant: Lemna perpusilla Torr.," Technical Report No. E8-TR-74016, Edgewood Arsenal, Aberdeen Proving Ground, Md.

Spanggord, R. J., Mill, T., Chou, T., Mabey, W. R., Smith, J. H., and Lee, S. 1980. "Environmental Fate Studies on Certain Munitions Wastewater Constituents: Phase II - Laboratory Studies," prepared for US Army Medical Research and Development Command, Fort Detrick, Md.

Spanggord, R. J., Mabey, W. R., Mill, T., Chou, T., Smith, J. H., Lee, S., and Roberts, D. 1983. "Environmental Fate Studies on Certain Munitions Wastewater Constituents: Phase IV - Lagoon Model Studies," prepared by SRI International, Menlo Park, Calif., for US Army Medical Bioengineering Research and Development Laboratory, Fort Detrick, Md.

Steel, R. G. D., and Torrie, J. H. 1980. Principles and Procedures of Statistics, A Biometrical Approach, 2d ed., McGraw-Hill, N. Y.

Tucker, W. A., Dose, E. V., Gensheimer, G. J., Hall, R. E., Pollman, C. D., and Powe1l, D. H. 1985. "Evaluation of Critical Parameters Affecting Contaminant Migration Through Soils," Vo1 I, Contract Report AMXTH-TE-TR-85030, prepared by Environmental Science and Engineering, Inc., Gainesville, Fla., for the US Army Toxic and Hazardous Materials Agency, Aberdeen Proving Ground, Md.

Weed, S. B., and Weber, J. B. 1974. "Pesticide-Organic Matter Interactions," Pesticides in Soil and Water, W. D. Guenzi, ed., Soil Science Society of America, Inc., Madison, Wis.

Won, W. D., DiSalvo, L. H., and $\mathrm{Ng}$, J. 1976. "Toxicity and Mutagenicity of 2,4,6-Trinitrotoluene and Its Microbial Metabolites," Applied and Environmental Microbiology, Vol 31, pp 576-580. 
Won, W. D., Heckley, R. J., Glover, D. J., and Hoffsommer, J. C. 1974.

"Metabolic Disposition of 2,4,6-Trinitrotoluene," Applied Microbiology, Vo1 27, No. 3, pp 513-516. 

APPENDIX A: STANDARD CURVES 



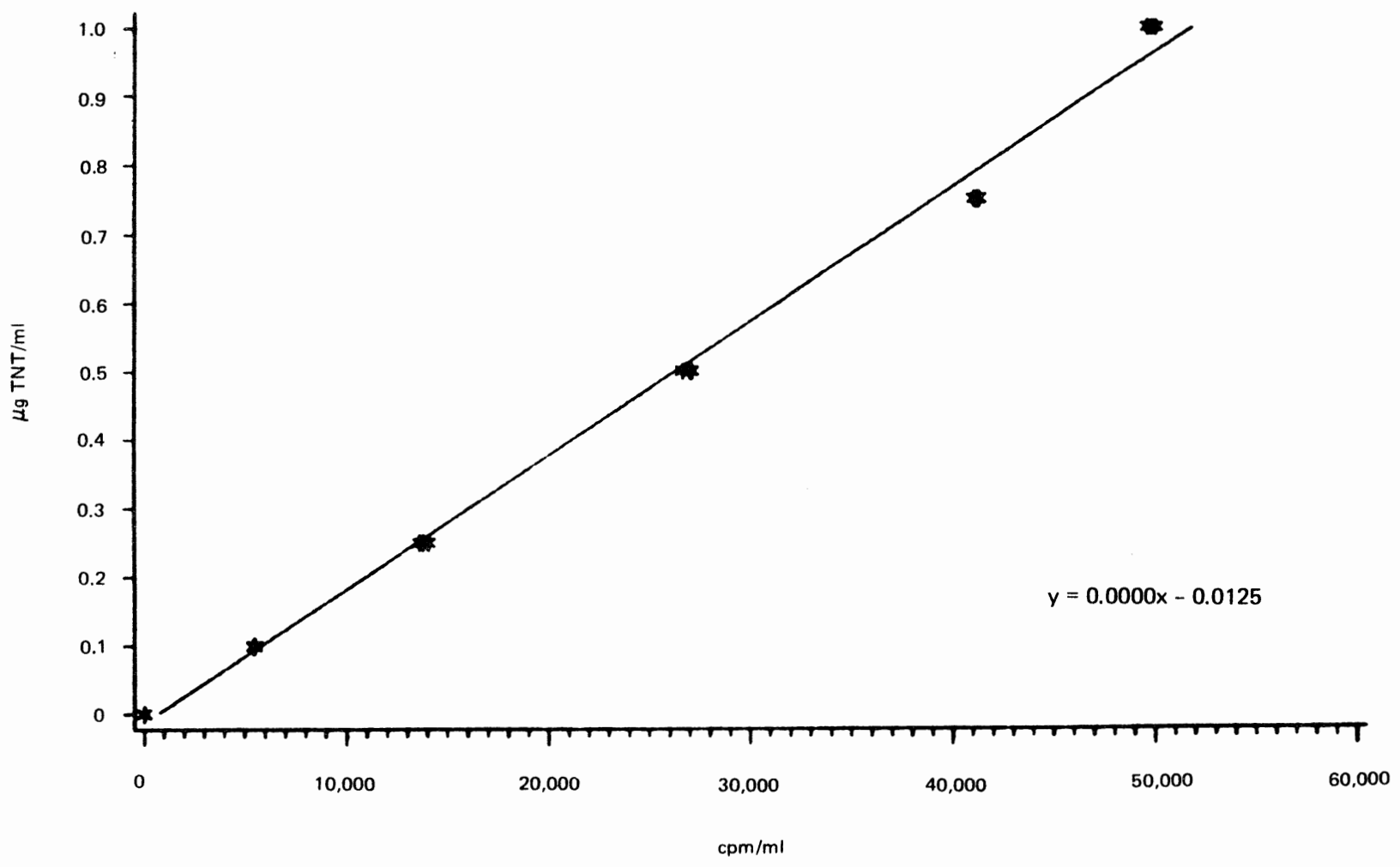

Figure Al. Standard curve relating counts per minute/millilitre to micrograms $\mathrm{TNT} / \mathrm{millilitre}$ in a $1.0-\mu \mathrm{g} \mathrm{TNT} / \mathrm{ml}$ solution containing $\left[{ }^{14} \mathrm{C}\right] \mathrm{TNT}$ 


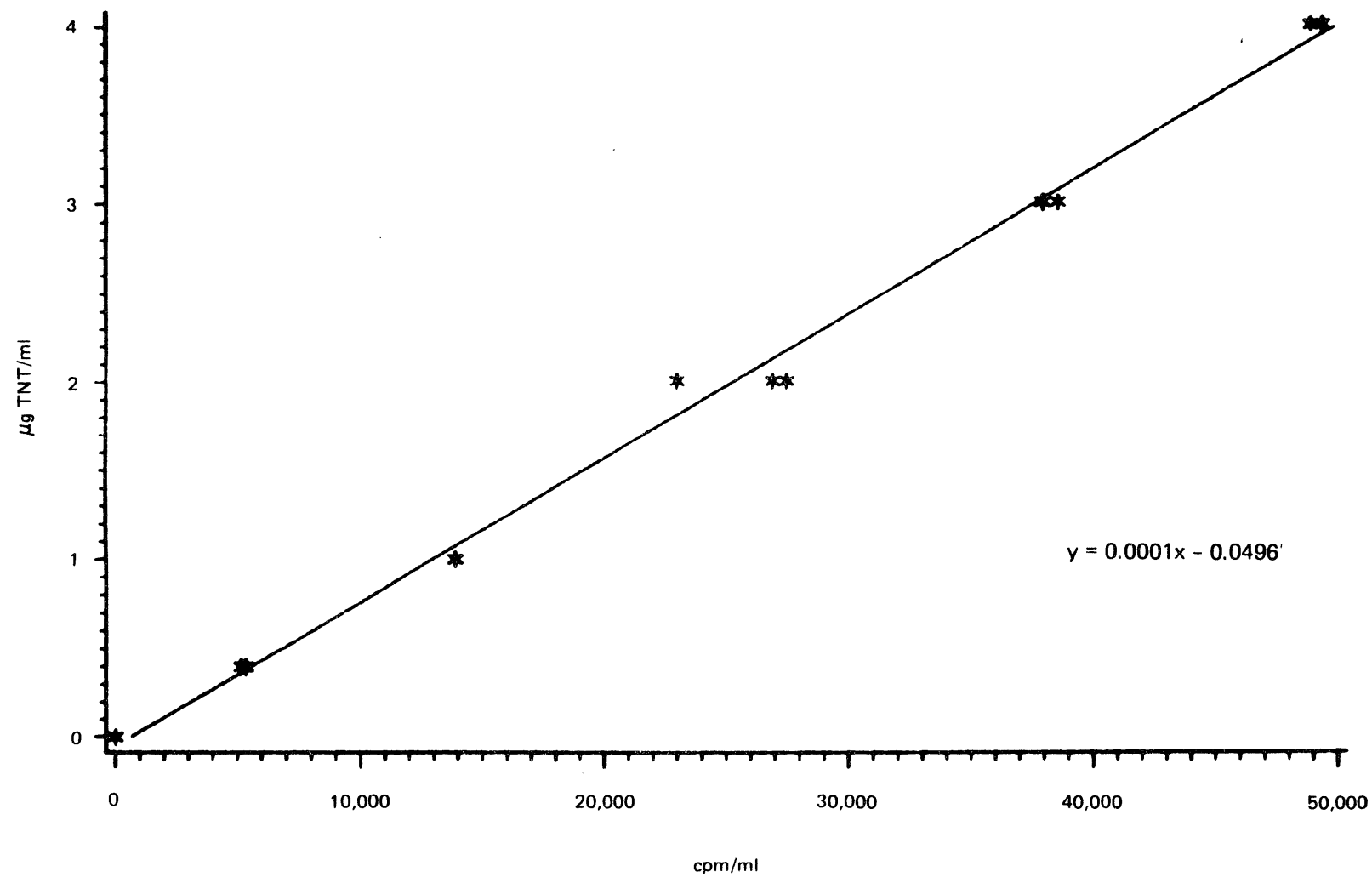

Figure A2. Standard curve relating counts per minute/millilitre to micrograms TNT/millilitre in a $4.0-\mu \mathrm{gNT} / \mathrm{ml}$ solution containing $\left[{ }^{14} \mathrm{C}\right] \mathrm{TNT}$ 


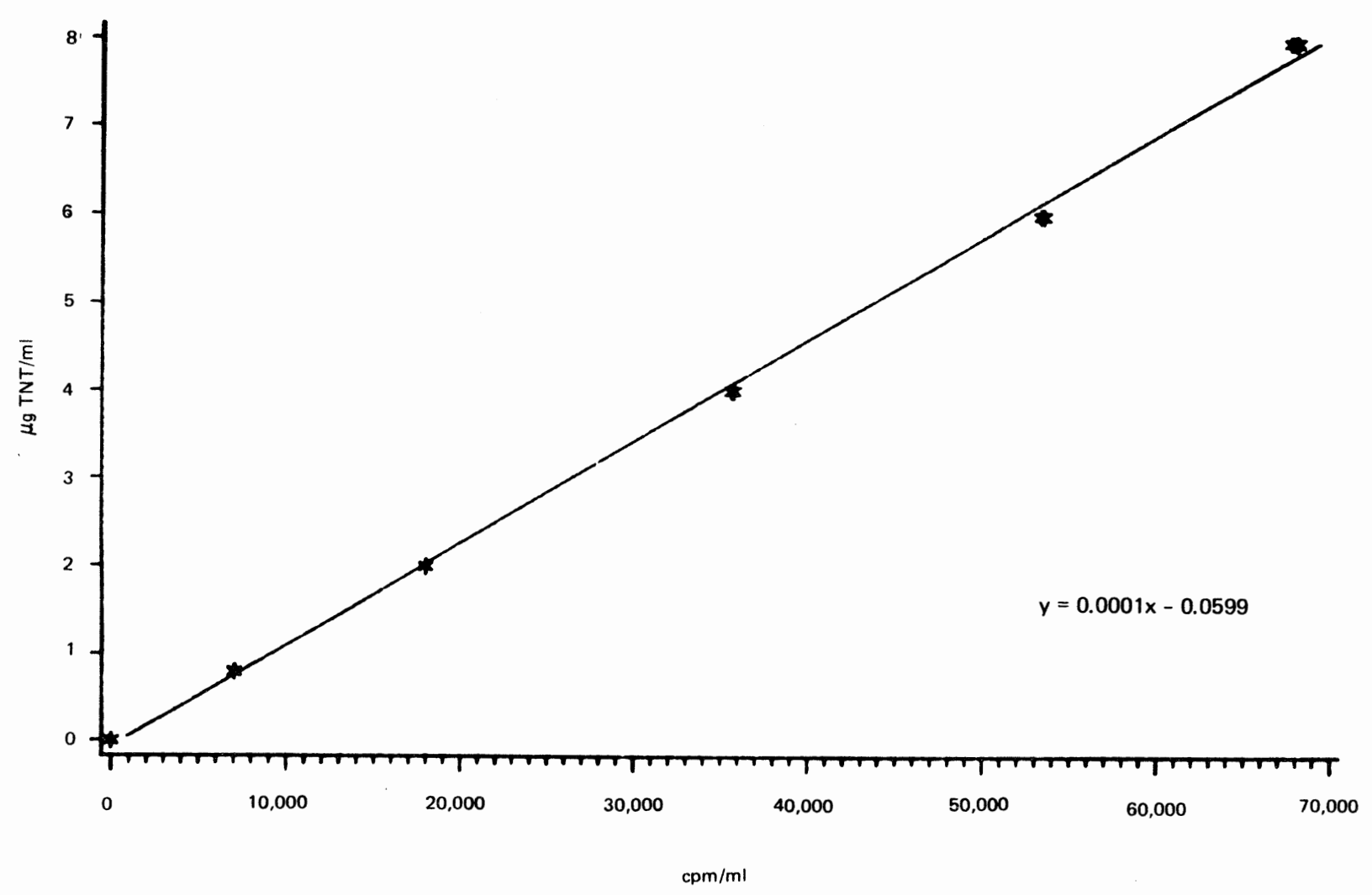

Figure A3. Standard curve relating counts per minute/millilitre to micrograms TNT/millilitre in an $8.0-\mu \mathrm{g} T \mathrm{TN} / \mathrm{m} 1$ solution

$$
\text { containing }\left[{ }^{14} \mathrm{C}\right] \mathrm{TNT}
$$




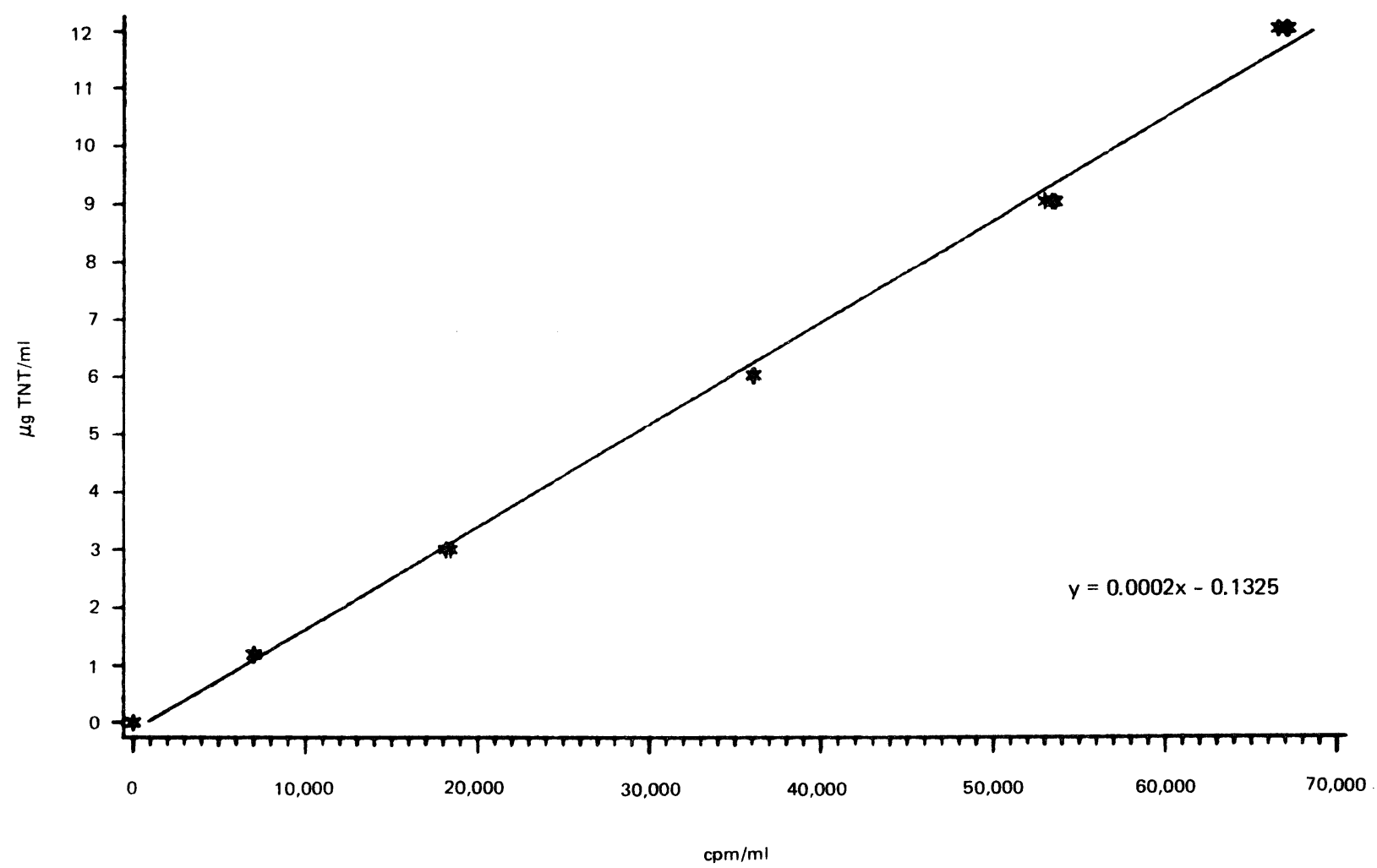

Figure A4. Standard curve relating counts per minute/millilitre to micrograms TNT/millilitre in a $12.0-\mu \mathrm{g} T \mathrm{TNT} / \mathrm{ml}$ solution containing $\left[{ }^{14} \mathrm{C}\right] \mathrm{TNT}$ 


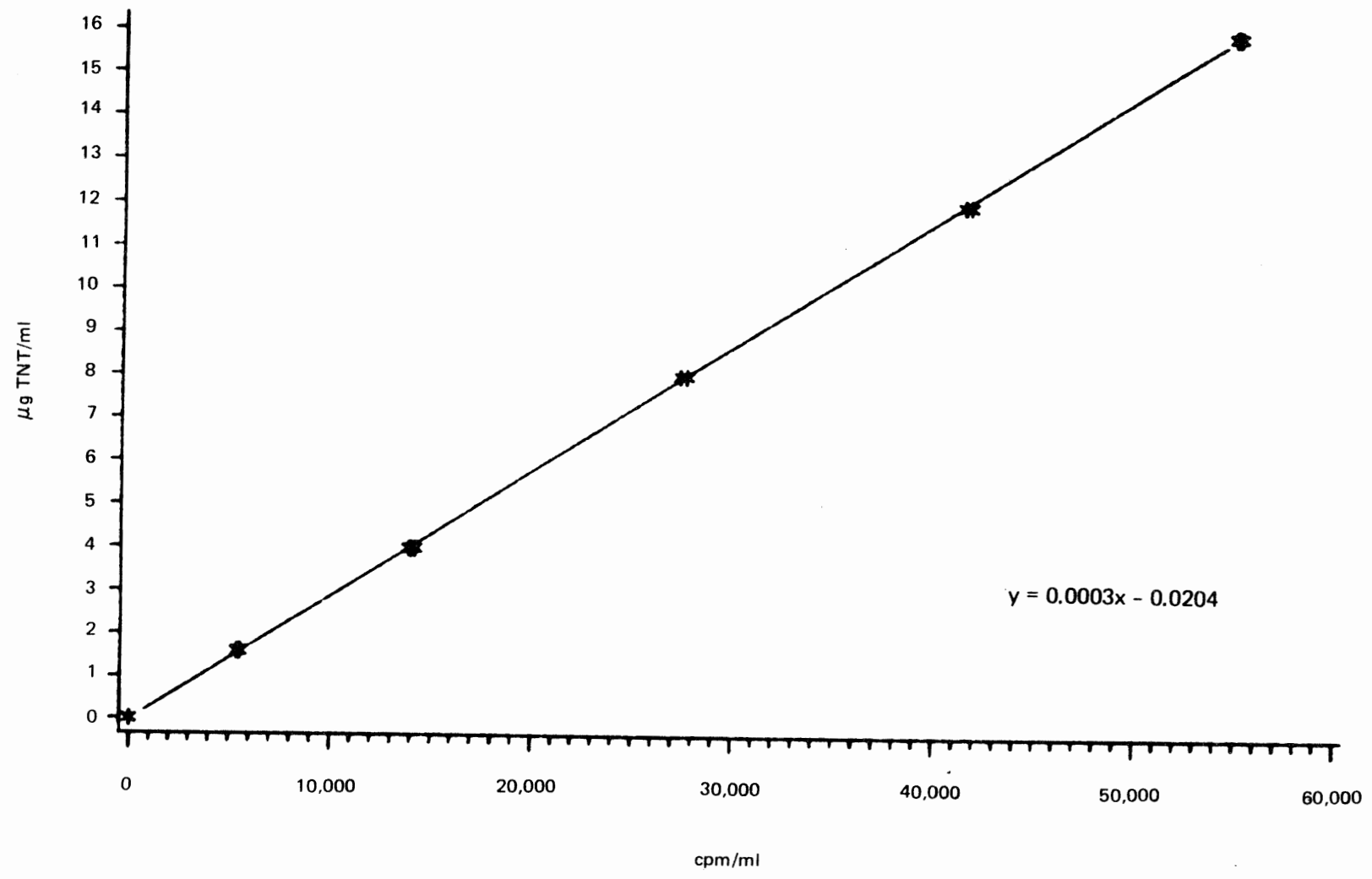

Figure A5. Standard curve relating counts per minute/millilitre to micrograms TNT/millilitre in a $16.0-\mu \mathrm{g} \mathrm{TNT} / \mathrm{ml}$ solution containing $\left[{ }^{14} \mathrm{C}\right]$ TNT 


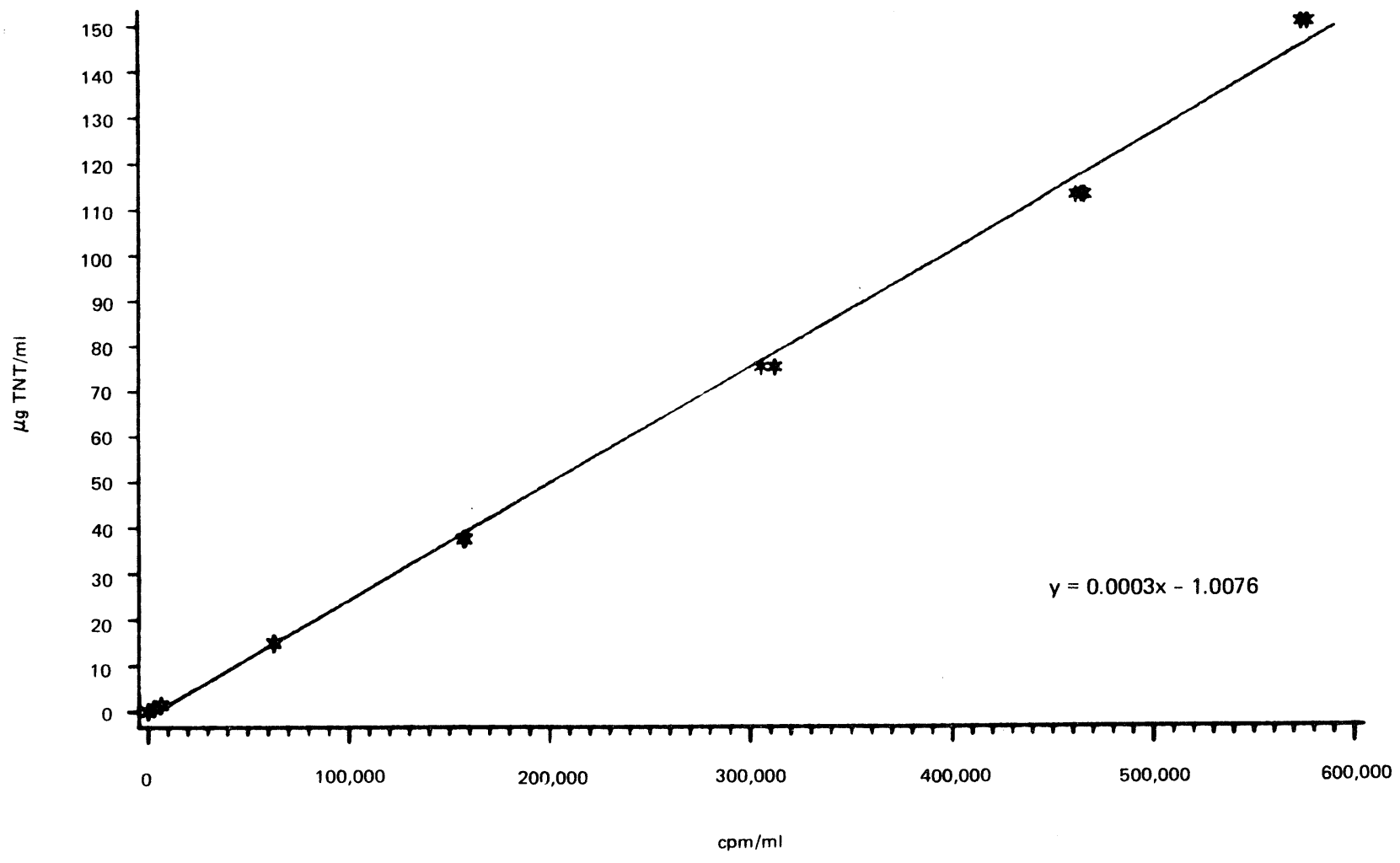

Figure A6. Standard curve relating counts per minute/millilitre to micrograms TNT/millilitre in a $150.0-\mu \mathrm{g} T \mathrm{TN} / \mathrm{ml}$ solution containing $\left[{ }^{14} \mathrm{C}\right] \mathrm{TNT}$ 
